Boston University School of Law

Scholarly Commons at Boston University School of Law

Faculty Scholarship

$12-2019$

\title{
Common Ownership and Executive Incentives: The Implausibility of Compensation as an Anticompetitive Mechanism
}

David I. Walker

Boston University School of Law

Follow this and additional works at: https://scholarship.law.bu.edu/faculty_scholarship

Part of the Antitrust and Trade Regulation Commons, Business Organizations Law Commons, Labor and Employment Law Commons, and the Law and Economics Commons

\section{Recommended Citation}

David I. Walker, Common Ownership and Executive Incentives: The Implausibility of Compensation as an Anticompetitive Mechanism, in 99 Boston University Law Review 2373 (2019).

Available at: https://scholarship.law.bu.edu/faculty_scholarship/592

This Article is brought to you for free and open access by Scholarly Commons at Boston University School of Law. It has been accepted for inclusion in Faculty Scholarship by an authorized administrator of Scholarly Commons at Boston University School of Law. For more information, please contact lawlessa@bu.edu. 


\title{
COMMON OWNERSHIP AND EXECUTIVE INCENTIVES: THE IMPLAUSIBILITY OF COMPENSATION AS AN ANTICOMPETITIVE MECHANISM
}

\author{
DAVID I. WALKER
}

\begin{abstract}
Mutual funds, pension funds, and other institutional investors are a growing presence in U.S. equity markets, and these investors frequently hold large stakes in shares of competing companies. Because these common owners might prefer to maximize the values of their portfolios of companies rather than the value of individual companies in isolation, this new reality has led to a concern that companies in concentrated industries with high degrees of common ownership might compete less vigorously with each other than they otherwise would. But what mechanism would link common ownership with reduced competition? Some commentators argue that one of the most plausible mechanisms is executive pay design. The idea is that executive pay at companies in concentrated industries with high common ownership may be designed to dampen the incentives of the companies' managers to compete aggressively with peer firms.

This Article challenges both the theoretical and empirical bases for this argument and contends that executive pay design is actually an implausible mechanism for linking common ownership with reduced competition. For example, this Article shows that, contrary to the claims of some commentators, the use of competition-enhancing executive relative performance evaluation as a compensation tool has increased dramatically in parallel with the increase in common ownership, exactly the opposite of what one would expect if common owners sought to dampen competition through pay design.

Despite voicing skepticism regarding a possible association between common ownership and executive pay design, this Article also offers suggestions for improving empirical analyses going forward that should help to resolve the debate. If, however, as this Article argues, executive paydesign is an implausible mechanism, this determination tends to undermine the broader claim that common ownership dampens interfirm competition.
\end{abstract}

\footnotetext{
* Professor of Law and Maurice Poch Faculty Research Scholar, Boston University School of Law. For their helpful comments and contributions, I am grateful to Jared Elias, Scott Hirst, Marcel Kahan, Yutian Luo, Rory Van Loo, and participants in a workshop at U.C. Hastings College of Law.
} 


\section{CONTENTS}

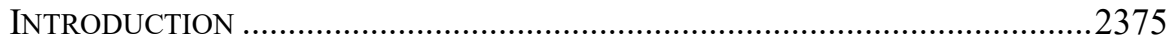

I. THE COMMON OWNERSHIP AND COMPETITION DEBATE....................2378

II. RELATIVE PERFORMANCE EVAluation AND COMMON

OWNERSHIP

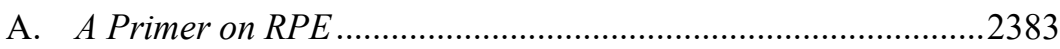

B. The Use of RPE in Executive Pay Contracts .............................2384

C. Why Did Companies Embrace Explicit RPE in the 2000s?

D. Avoidance of RPE Is Unlikely to Be a Mechanism by Which Common Owners Discourage Interfirm Competition

E. A New Challenge to the Empirical Evidence on the Association Between Common Ownership and the Use of RPE...

III. COMMON OWNERSHIP AND THE SENSITIVITY OF

EXECUTIVE WEALTH TO OWN-FIRM PERFORMANCE

A. The Revised AEGS Approach in Detail

B. Concerns with the Revised AEGS Approach

1. Low WPS Is Inconsistent with Common-Owner

Preferences 2401

2. Executive WPS Is Difficult to Adjust over the Short

to Medium Term 2403

a. Adjusting WPS Through Current Compensation..........2404

b. Adjusting WPS Through Previously Issued Compensation ……........................................................2407

c. Adjusting WPS Associated with Vested Stock...............2407

3. Methodological Concerns with a WPS-Based

Assessment of Incentives 2409

IV. TOWARD AN IMPROVED EMPIRICAL STRATEGY 


\section{INTRODUCTION}

An important emerging literature investigates the relationship between increasing institutional investor ownership of multiple companies within an industry and competition between these companies. Institutional investor ownership of U.S. equity securities has skyrocketed over the last several decades. These investors are currently estimated to hold $70-80 \%$ of the shares of the S\&P 500. ${ }^{1}$ Unsurprisingly, institutional common ownership of companies within various industries has risen steeply as well. Between 1980 and 2010, the fraction of U.S. public companies with a $5 \%$ institutional shareholder holding of at least $5 \%$ of a competitor company increased from $10 \%$ to $60 \% .{ }^{2}$ Neither trend shows signs of abating.

The theoretical implications for competition are simple: unlike an investor in a single company, an investor who owns large stakes in competing companies $A, B$, and $C$ has an interest in the profitability of the three companies in the aggregate and may not benefit from intense competition between the three companies, which could drive down aggregate returns. If the managers of $A, B$, and $C$ respond to these common-owner preferences, they will compete less aggressively. Two recent papers provide evidence of such anticompetitive effects in the airline and banking industries, ${ }^{3}$ but the results of these papers and the broader issues are hotly contested. ${ }^{4}$

A key question in this debate is: What mechanism would translate the anticompetitive preferences of common owners into competition-reducing actions by the managers of the commonly held companies? To a significant degree, the persuasiveness of the anticompetitive narrative depends on the identification of a plausible mechanism.

For many commentators, executive pay design is a leading candidate. The idea is that executive pay arrangements at companies in industries with high

\footnotetext{
1 See Einer Elhauge, Horizontal Shareholding, 129 HARV. L. REV. 1267, 1268 (2016) (citing Neil Stewart, Retail Shareholders: Looking Out for the Little Guy, IR MAG. (May 15, 2012), https://www.irmagazine.com/shareholder-targeting-id/retail-shareholders-lookingout-little-guy [https://perma.cc/YD5Y-RS4E]); Marshall E. Blume \& Donald B. Keim, Institutional Investors and Stock Market Liquidity: Trends and Relationships 4 (Aug. 21, 2012) (unpublished manuscript), https://papers.ssrn.com/sol3/papers.cfm?abstract_id=21 47757 [https://perma.cc/FNS2-85MM] (finding that institutions held $67 \%$ of value of all U.S. shares in 2010).

${ }^{2}$ See Jie (Jack) He \& Jiekun Huang, Product Market Competition in a World of CrossOwnership: Evidence from Institutional Blockholdings, 30 REV. FIN. STUD. 2674, 2675 (2017).

3 See generally José Azar, Martin C. Schmalz \& Isabel Tecu, Anticompetitive Effects of Common Ownership, 73 J. FIn. 1513 (2018) (airline industry); José Azar, Sahil Raina \& Martin C. Schmalz, Ultimate Ownership and Bank Competition (May 4, 2019) (unpublished manuscript), https://papers.ssrn.com/sol3/papers.cfm?abstract_id=2710252 [https://perma.cc /WU9E-9HP8] (banking sector).

${ }^{4}$ See infra Part I.
} 
levels of common ownership may be designed to dampen managerial incentives to compete aggressively with peer firms..$^{5}$ Empirical papers investigating this possibility have taken two approaches.

First, a number of papers have investigated whether common ownership is associated with the use of executive relative performance evaluation ("RPE"). ${ }^{6}$ As the term suggests, RPE-based compensation rewards executives for company performance relative to that of peer firms. ${ }^{7}$ Since a manager with a strong RPEbased contract can profit by increasing own-firm performance or depressing peer-firm performance, RPE-based arrangements tend to encourage aggressive competition between companies and therefore would not be preferred-so the thinking goes - by investors with large common ownership stakes. In a highly cited working paper, Miguel Anton, Florian Ederer, Mireia Giné, and Martin C. Schmalz ("AEGS") reported evidence of a negative association between common ownership and the use of RPE, ${ }^{8}$ but others have found evidence of a positive association ${ }^{9}$ or of no association. ${ }^{10}$

Second, recognizing that managerial incentives are a function of equity holdings as well as current compensation arrangements, AEGS have revised their working paper, replacing RPE measures as their dependent variables with various measures of the sensitivity of an executive's wealth to own-firm performance. ${ }^{11}$ They predict and find that greater common ownership is

\footnotetext{
${ }^{5}$ See respectively Miguel Anton et al., Common Ownership, Competition, and Top Management Incentives 1 (Cowles Found., Discussion Paper No. 2046, 2016), https:/cowles.yale.edu/sites/default/files/files/pub/d20/d2046.pdf [https://perma.cc/4VMBMYC9] [hereinafter AEGS (2016)]; Miguel Anton et al., Common Ownership, Competition, and Top Management Incentives 1 (ECGI Working Paper Series in Fin., Working Paper No. 511/2017, 2018), https://papers.ssrn.com/sol3/papers.cfm?abstract_id=2802332 [https:// perma.cc/YU74-AMMG] [hereinafter AEGS (2018)]; Azar, Schmalz \& Tecu, supra note 3, at 1556-57; Azar, Raina \& Schmalz, supra note 3, at 5.

${ }^{6}$ See, e.g., AEGS (2016), supra note 5, at 2-3 (describing their model calculating RPE); Rebecca DeSimone, Stealth Socialism? Common Ownership and Executive Incentives 2 (Oct. 7, 2017) (unpublished manuscript) (on file with author); Heung Jin Kwon, Executive Compensation Under Common Ownership 1 (Nov. 29, 2016) (unpublished manuscript), http://fmaconferences.org/Boston/ExecutiveCompensationunderCommonOwnership.pdf [https://perma.cc/ES7W-FF7G]; Lantian (Max) Liang, Common Ownership and Executive Compensation 1 (Oct. 2016) (unpublished manuscript), https://acfr.aut.ac.nz/_data/assets /pdf_file/0008/58085/43082-L-Liang-Common_ownership_V2.pdf [https://perma.cc/LU9EUU5Z].

7 See Bengt Holmstrom, Moral Hazard in Teams, 13 Bell J. Econ. 324, 334-39 (1982) (showing that RPE-based contracts can improve risk sharing).

8 AEGS (2016), supra note 5, at 54 (finding negative association between common ownership and use of RPE); see also Liang, supra note 6, at 5 (same).

${ }^{9}$ See Kwon, supra note 6, at 17.

10 See DeSimone, supra note 6, at 13.

${ }^{11}$ See generally AEGS (2018), supra note 5.
} 
associated with lower wealth-to-performance sensitivity, that is, with lowerpowered, or "flatter" incentives that would, they suggest, result in less competition with peer firms. ${ }^{12}$

This Article argues that executive pay design is actually not a plausible mechanism linking common ownership with reduced competition. It argues that executive pay design is a poor fit from a theoretical or conceptual standpoint, that the trends in executive pay over the last twenty years are inconsistent with this narrative, and that the empirical methods used to establish the purported relationship are flawed in ways that have not been identified by previous commentators. The analysis proceeds in four main parts.

Part I briefly recaps the evidence and debate concerning the growth of institutional investor common ownership and the resulting impact on competition between commonly held companies. This Part also highlights the key question of the mechanism linking the two and the importance of executive pay design as a leading mechanism.

Part II considers the possible relationship between common ownership and the use of RPE. This Part shows that the macro trends run exactly counter to the idea of executive pay serving as a mechanism for discouraging competition in industries with high levels of common ownership. If common owners discourage the use of RPE, one would expect reduced use of RPE over the last several decades as common ownership has mushroomed, but just the opposite is true. Prior to 2000, there was very little use of RPE in long-term executive pay arrangements at U.S. public companies. In the last two decades, use of explicit RPE has increased dramatically. Part II also offers other reasons to doubt that the use of RPE is a function of common ownership; for example, specific design elements of RPE are inconsistent with purported common-owner preferences. Finally, Part II identifies a serious flaw in the identification of RPE utilized in the empirical studies that find a negative relationship between common ownership and use of RPE. In short, the methodology is appropriate for identifying executive incentives associated with implicit RPE, but not appropriate for identifying executive incentives associated with explicit RPE, which now likely dominates. ${ }^{13}$

Part III turns to the idea that the sensitivity of managerial wealth to own-firm performance ("WPS") may be a function of common ownership and considers the evidence, focusing on three primary critiques. First, the use of lowerpowered incentives to discourage competition seems an unrealistically rough lever. Lower-powered incentives would not only discourage aggressive competition, but they would also discourage noncompetitive efforts to increase profits, such as through industry lobbying. This is both counterintuitive and at least facially inconsistent with the publicly stated positions of large institutional

\footnotetext{
12 Id. at 2-4.

13 As described infra Section II.A, explicit RPE metrics are directly incorporated into compensation instruments. Implicit RPE arises when discretionary elements of compensation are adjusted to reflect relative performance.
} 
investors. Second, while compensation committees can easily adjust the level of RPE in current compensation contracts, their ability to manage WPS over the short to medium term is much more attenuated. Thus, evidence based on shortterm differences in WPS seems particularly difficult to square with the theory. Third, it is very difficult to determine WPS associated with the complex performance share awards that have come to dominate executive pay arrangements in recent years, and it is unclear whether or how empiricists have dealt with this problem.

For the reasons discussed in Parts II and III, this Article concludes that executive pay design is an implausible mechanism for linking common ownership to anticompetitive behavior. From an empirical perspective, however, one can only say that such an association has not been convincingly demonstrated. In the spirit of helping to resolve the question, Part IV offers several suggestions for improving future empirical work on the possible association. This Part argues that a focus on RPE is more promising than a focus on WPS, although WPS should certainly serve as a control; that a convincing empirical strategy must include both implicit and explicit RPE; and that specific design features of explicit RPE-based compensation should be incorporated in future analyses.

This Article concludes by emphasizing the importance of the mechanism question to the broader debate. Commentators relying on executive pay design as the mechanism linking common ownership to anticompetitive behavior would be advised to consider other mechanisms. In the meantime, one should be cautious in advocating regulatory intervention with respect to common ownership practices.

\section{THE COMMON OWNERSHIP AND COMPETITION DEBATE}

This Part briefly surveys the growth in institutional common ownership of U.S. companies, the purported implications for product market competition, and the evidence. It highlights the debate between commentators who favor regulatory intervention and those who urge caution. Finally, it homes in on the key question of the mechanism linking common ownership to anticompetitive behavior and the prominence of executive pay design as a leading mechanism.

As noted in the Introduction, institutional investor ownership of U.S. equities has increased dramatically in recent years. This has led to an equally dramatic increase in the number of cases in which common owners hold large positions in multiple companies within an industry. Much of the growth in institutional equity ownership and common ownership is attributable to positions held by stock market index funds, the most rapidly growing segment of the institutional investor market. ${ }^{14}$ The modus operandi of index funds, of course, is to own all

14 See Lucian A. Bebchuk \& Scott Hirst, Index Funds and the Future of Corporate Governance: Theory, Evidence, and Policy, 119 Colum. L. REv. (forthcoming Dec. 2019) 
of the companies that the index tracks - that is, all of the companies included in the S\&P 500, the Russell 3000 , or whatever index is selected. ${ }^{15}$ As a result, index fund families' common ownership of the leading companies in most industries is essentially inevitable. According to a recent study, the holdings of the "Big Three" index fund families-BlackRock, State Street, and Vanguard-taken together would represent the largest shareholder of 438 of the S\&P 500 companies. ${ }^{16}$

Recent papers by José Azar, Martin C. Schmalz, and Isabel Tecu and by Azar, Sahil Raina, and Schmalz sparked concern about the possible anticompetitive aspects of increasing common ownership. ${ }^{17}$ As Azar, Schmalz, and Tecu explain:

[W]ithin-industry diversification of influential shareholders can lead to less competition in portfolio firms' product markets. To see why, imagine an industry with two equal-sized firms, A and B. Suppose A undercuts B's price to attract customers from B and thus gain market share. Depending on the parameters, firm A may benefit from such a move by selling many more units of a product at an only slightly reduced price. Variations of this logic are the basis for many standard models of competition.

However, A's gain in market share comes at the expense of firm B's market share, and average prices in the market are lower. As a result, the owner of firm B loses more revenue than the owner of firm A gains and thus the sum of A's and B's producer rents falls. This means that an investor holding equal-sized stakes in both A and B would enjoy greater total (i.e., portfolio) profits if the two firms set prices or quantities as if they were two divisions of a monopoly instead of as two independent firms. We therefore expect less competition compared to the standard model, to the extent that shareholders are diversified across natural competitors and portfolio firms act in their diversified shareholders' interest. ${ }^{18}$

In their empirical analyses, these authors find associations between institutional investor common ownership and reduced competition between companies in the airline and banking industries. ${ }^{19}$ Specifically, Azar, Schmalz, and Tecu find that taking common ownership into account results in market

(manuscript at 1), https://papers.ssrn.com/sol3/papers.cfm?abstract_id=3282794 [https:// perma.cc/53S7-N2PS] (noting dramatic increase in assets held by index funds).

15 Id. (manuscript at 11-12).

${ }^{16}$ Jan Fichtner, Eelke M. Heemskerk \& Javier Garcia-Bernardo, Hidden Power of the Big Three? Passive Index Funds, Re-Concentration of Corporate Ownership, and New Financial Risk, 19 Bus. \& Pol. 298, 313 (2017).

17 See Azar, Schmalz \& Tecu, supra note 3, at 1558; Azar, Raina \& Schmalz, supra note 3 , at 15 .

18 Azar, Schmalz \& Tecu, supra note 3, at 1521. The companies whose shares are held by institutional investors are referred to as "portfolio" companies.

19 Id. at 1513 (airlines); Azar, Raina \& Schmalz, supra note 3, at 5 (banking). 
concentration within the U.S. airline industry that is ten times larger than the level presumed to be likely to enhance market power per Federal Trade Commission and Department of Justice guidelines..$^{20}$ And they produce evidence of a positive association between ticket prices and the degree of common ownership of airlines serving various routes. ${ }^{21}$ Azar, Raina, and Schmalz examine the impact of common ownership and cross-ownership of U.S. banks and find that, taking these ownership features into account, regional industry concentration is correlated with bank fees and deposit thresholds. ${ }^{22}$

These papers have been highly influential, but also controversial. Several researchers have questioned the strength of the empirical evidence and/or the theoretical underpinnings. For example, Daniel O'Brien and Keith Waehrer argue that the regressions in these papers are misspecified in such a way as to lead to a correlation between common ownership and product prices even if there is no causal connection. ${ }^{23}$ More generally, they question the use of the modified Herfindahl-Hirschman Index ("MHHI") as the measure of common ownership in these papers, arguing that the MHHI "does not provide a reliable prediction of the effects of common ownership" on product prices in oligopolistic markets. ${ }^{24}$ Edward Rock and Daniel Rubinfeld argue that managers

20 Azar, Schmalz \& Tecu, supra note 3, at 1526.

${ }^{21}$ See id. at 1559 ("[W]e find that airline ticket prices are 3\% to 7\% higher due to common ownership ....").

${ }^{22}$ See Azar, Raina \& Schmalz, supra note 3, at 3. While common ownership refers to an investor holding shares in competing companies, cross-ownership refers to one company in an industry holding shares in a competitor. See id. at 2.

${ }^{23}$ See Daniel P. O'Brien \& Keith Waehrer, The Competitive Effects of Common Ownership: We Know Less than We Think, 81 ANTITRUST L.J. 729, 732 (2017).

${ }^{24}$ Id. at 744; see also Erik P. Gilje, Todd A. Gormley \& Doron Levit, Who's Paying Attention? Measuring Common Ownership and Its Impact on Managerial Incentives, J. FIN. ECON. (forthcoming 2020) (manuscript at 3), https://papers.ssrn.com/sol3 /papers.cfm?abstract_id=3165574 [https://perma.cc/3H5M-4AH7] (arguing that MHHI measure unrealistically assumes that all investors are fully attentive); Jacob Gramlich \& Serafin Grundl, Testing for Competitive Effects of Common Ownership 2 (Fed. Reserve Bd. Fin. \& Econ. Discussion Series, Working Paper No. 2017-029, 2017), https://www.federal reserve.gov/econres/feds/files/2017029pap.pdf [https://perma.cc/S5AZ-3EC5] (criticizing use of MHHI and proposing alternative). The MHHI is a generalization of the HHI, which has long been used in antitrust analysis as a measure of industry concentration. Modifications introduced by Timothy Bresnahan and Steven Salop and by Daniel O'Brien and Salop take into account partial ownership and common ownership. See Timothy F. Bresnahan \& Steven C. Salop, Quantifying the Competitive Effects of Production Joint Ventures, 4 INT'L J. INDUS. ORG. 155, 155 (1986) ("We focus on the impact of the financial interest and management control strucutre of the venture.”); Daniel P. O'Brien \& Steven C. Salop, Competitive Effects of Partial Ownership: Financial Interest and Corporate Control, 67 ANTITRUST L.J. 559, 561-62 (2000); see also Menesh S. Patel, Common Ownership, Institutional Investors, and Antitrust, 82 ANTITRUST L.J. 279, 325-28 (2018) (arguing that whether common ownership 
are unlikely to take investor common ownership incentives into account given the conflicting and constantly changing positions of their institutional shareholders, including interests in suppliers and customers of these companies. ${ }^{25}$

Despite the theoretical and empirical challenges to the banking and airline papers, a number of legal scholars have concluded that the evidence is sufficiently clear to warrant regulatory action addressing the adverse effects of common ownership on competition. Concluding that the "evidence now firmly establish[es] that high levels of horizontal shareholding in concentrated markets often has anticompetitive effects," Einer Elhauge argues that existing U.S. and E.U. antitrust regulation should be brought to bear. ${ }^{26}$ Eric Posner, Fiona Scott Morton, and Glen Weyl propose limiting investors' aggregate holdings in oligopolistic industries to $1 \%$ of the industry unless investors elect to hold only a single company within such an industry. ${ }^{27}$

Other commentators urge caution. Scott Hemphill and Marcel Kahan note that while placing limitations on common ownership might be viewed as a "better safe than sorry" strategy from an antitrust perspective, discouraging common owners from participating in corporate governance could be costly. ${ }^{28}$ Given their misgivings regarding the evidence and finding the Posner, Scott Morton, and Weyl proposal unduly severe, Rock and Rubinfeld suggest the creation of an antitrust safe harbor for institutional investors who limit ownership to $15 \%$ of a given company's equity, do not have board representation, and engage in only "normal" corporate governance activities. ${ }^{29}$ Obviously, the legal and regulatory stakes here are very high. ${ }^{30}$

will actually generate competitive harm in a particular industry depends on a number of factors and requires case-by-case analysis).

25 See Edward B. Rock \& Daniel L. Rubinfeld, Antitrust for Institutional Investors, 82 ANTITRUST L.J. 221, 230-39 (2018).

${ }^{26}$ Einer R. Elhauge, New Evidence, Proofs, and Legal Theories on Horizontal Shareholding 40 (Jan. 4, 2018) (unpublished manuscript), https://ssrn.com/abstract=3096812 [https://perma.cc/T87Y-7S6P] (suggesting that U.S.'s Sherman and Clayton Acts and E.U.'s TFEU Article 101 can help regulate anticompetitive horizontal shareholding); see also Fiona Scott Morton \& Herbert Hovenkamp, Horizontal Shareholding and Antitrust Policy, 127 YALE L.J. 2026, 2047 (2018) (concluding that "Section 7 of the Clayton Act presents a promising vehicle for combatting the anticompetitive effects of horizontal shareholding").

27 See Eric A. Posner, Fiona M. Scott Morton \& E. Glen Weyl, A Proposal to Limit the Anticompetitive Power of Institutional Investors, 81 ANTITRUST L.J. 669, 670 (2017).

${ }^{28}$ C. Scott Hemphill \& Marcel Kahan, The Strategies of Anticompetitive Common Ownership, YALE L.J. (forthcoming) (manuscript at 52-53), https://papers.ssrn.com/sol3 /papers.cfm?abstract_id=3210373\#\# [https://perma.cc/W7UR-LKUT].

29 See Rock \& Rubinfeld, supra note 25, at 270-77.

${ }^{30}$ To gain a sense of the importance of these questions and this debate, note that the Azar, Schmalz, and Tecu airline industry paper - which was only recently published in the Journal of Finance, supra note 3-has been downloaded on SSRN over 12,500 times as of November 
An important question in this debate concerns the mechanism linking the portfolio-maximizing incentives of institutional investors and the anticompetitive actions of the managers of particular companies. How would the managers of these companies be induced to refrain from vigorous competition with peer firms? Azar, Schmalz, and Tecu suggest a number of potential mechanisms: common owners may influence portfolio company management by engaging with them directly, by creating managerial incentive structures that discourage competition, by electing directors sympathetic to avoiding vigorous competition, or by doing nothing. ${ }^{31}$ The final idea is that competing with peer firms is personally costly for managers. If common owners fail to push managers to compete, they will tend to refrain from competing and simply enjoy the "quiet life." 32

Hemphill and Kahan provide numerous reasons to question these and other proposed mechanisms linking common ownership with reduced competition. ${ }^{33}$ They point out that several mechanisms have not been empirically tested and that others are implausible. ${ }^{34}$ They are skeptical that common owners would prefer the adoption of weak managerial incentives as a means of discouraging competition, but conclude that avoiding the use of relative performance evaluation at firms in industries with a high degree of common ownership is more plausible. ${ }^{35}$ They also conclude that "selective omission," or passivity, of common owners in cases in which firm value and portfolio value conflict is another plausible mechanism. ${ }^{36}$

In a series of draft papers, AEGS show as a theoretical matter that common owners could discourage interfirm competition by "failing to offer managerial compensation that is as performance-sensitive as the compensation provided by

2019. See José Azar, Martin C. Schmalz \& Isabel Tecu, Anticompetitive Effects of Common Ownership, SSRN (Apr. 22, 2014), https://papers.ssrn.com/sol3/papers.cfm?abstract_id= 2427345 [https://perma.cc/U54U-WND5] (indicating 12,598 downloads as of November 29, 2019).

31 See Azar, Schmalz \& Tecu, supra note 3, at 1552-58.

32 Id. at $1552-53$.

33 See Hemphill \& Kahan, supra note 28 (manuscript at 47-49). Hemphill and Kahan also note the lack of strong incentives on the part of institutional common owners to undertake costly or risky actions to increase portfolio values. $I d$. (manuscript at 40). Index-focused investors, in particular, have traditionally been viewed as passive. See id. (manuscript at 45). Their economic incentives are to provide investment opportunities that accurately track indexes at the lowest possible cost. Id. (manuscript at 44-46). As such, some commentators conclude that these funds are unlikely to invest resources in attempting to shape corporate policy or governance. See, e.g., Bebchuk \& Hirst, supra note 14 (manuscript at 79) (concluding that "index fund managers have inadequate incentives to engage in stewardship aimed at enhancing the value of particular companies").

${ }^{34}$ Hemphill \& Kahan, supra note 28 (manuscript at 6-8).

${ }^{35}$ Id. (manuscript at 21-22).

${ }^{36}$ Id. (manuscript at 30-31). 
undiversified owners." ${ }^{37}$ They provide empirical evidence indicating that, as predicted by their theory, companies with a high degree of common ownership tend to make less use of relative performance evaluation ${ }^{38}$ and tend to adopt less high-powered incentives generally. ${ }^{39}$ Because establishing a plausible mechanism linking common ownership to reduced competition is a critical step in the broader debate, it is important to review these claims carefully, and that is the purpose of the remainder of this Article.

\section{RELATIVE PERFORMANCE EVALUATION AND COMMON OWNERSHIP}

This Part considers the theory and evidence linking executive RPE to common ownership and interfirm competition. It begins by recapping the theoretical connections. Next, it briefly traces the evolution of executive pay design over the last thirty years, roughly the period during which common ownership has become prevalent. The key takeaway is that explicit use of RPE has increased dramatically in tandem with the growth in common ownershipexactly the opposite of what one would predict if reduced use of RPE were a mechanism for translating the anticompetitive preferences of common owners into reduced competition. Finally, this Part addresses the empirical literature connecting RPE with common ownership and argues that the evidence of a negative association supporting the compensation mechanism hypothesis is unpersuasive. This Part points out a critical shortcoming in the literature: a focus on an empirical strategy that properly identifies implicit use of RPE but not the explicit use of RPE, which likely now dominates.

\section{A. A Primer on RPE}

Nobel economics laureate Bengt Holmstrom demonstrated in the 1980s that executive compensation arrangements could be made more efficient by employing relative performance measures that would filter out the noise of industry or market movements over which executives have no control. ${ }^{40}$ Instead of basing a bonus solely on a company's total shareholder return, for instance, the bonus could be based on the company's total return relative to the total return of a select group of peer companies or of a broad group of companies. RPE metrics both filter out uncontrollable risks (seemingly attractive to executives) and reduce compensation windfalls associated with general market rises (seemingly attractive to investors).

RPE-based compensation can either be explicit or implicit. The relative total shareholder return-based bonus described in the preceding paragraph is an example of explicit RPE. Relative performance is built into the bonus targets. In other cases, however, a company's board might use its discretion to adjust salary

37 AEGS (2018), supra note 5, at 2.

38 See AEGS (2016), supra note 5, at 28.

39 See AEGS (2018), supra note 5, at 3-4.

${ }^{40}$ Holmstrom, supra note 7, at 334-38. 
levels or bonus payouts based in part on the firm's performance relative to other companies along any number of metrics. This would be an example of implicit RPE. All else equal, the introduction of RPE, whether explicit or implicit, but anticipated, encourages competition with peer firms, since managers can enhance relative performance by improving own-firm performance or by taking actions that reduce peer-firm performance.

Of course, all else is not always equal. The selection of the peer group is critical to the creation of competitive incentives. Consider, for example, two RPE-based bonus schemes. One is based on shareholder return relative to a dozen close competitors. The other is based on shareholder return relative to all of the members of the Russell 3000 index (which includes the dozen peer firms). In each case, the bonus is a function of the company's rank among the benchmarked companies. The first design most pointedly encourages competition with peer companies, since undermining the performance of one or more of these dozen firms would materially improve the company's rank among the thirteen and thus an executive's bonus. On the other hand, depressing the performance of one or more peer firms is unlikely to materially affect the company's shareholder return ranking among the Russell 3000 companies, and thus the latter design is less likely to affect competition between rival firms.

The nature of RPE-based metrics is also important. Schmalz argues that RPE metrics reflecting company value creation, such as total shareholder return, encourage product market competition with peer firms, while margin-based metrics actually discourage such competition. ${ }^{41}$ For example, a company might increase its relative profits and returns by increasing output and market share, but in order to maximize margins relative to its peers, a company would tend to restrict its output. ${ }^{42}$ All else equal, common owners would prefer that their portfolio companies restrict output and push up prices. So it is feasible that companies might embrace RPE while selecting metrics that do not encourage fierce product market competition between commonly owned peer firms.

\section{B. The Use of RPE in Executive Pay Contracts}

Prior to the mid-2000s, RPE played a relatively insignificant role in U.S. public company executive pay arrangements. ${ }^{43}$ This situation changed dramatically in the mid- to late-2000s and 2010s as performance awards, often including explicit RPE metrics, supplanted stock options as the dominant equity

${ }^{41}$ See Martin Schmalz, Presentation at FTC Hearing \#8 on Competition and Consumer Protection in the 21st Century: Competitive Harm from Common Ownership: Common Ownership Theories, Governance "Mechanisms" \& Policy 63 (Dec. 6, 2018).

${ }^{42}$ See id.

43 See David I. Walker, The Way We Pay Now: Understanding and Evaluating Performance-Based Executive Pay, 1 J.L. Fin. \& AcCT. 395, 399 (2016) ("Conventional stock options, and to a lesser extent restricted stock, reigned supreme during the early years of the equity pay era."). 
pay instrument. ${ }^{44}$ RPE is undoubtedly a larger feature of executive pay design today than ever before. This Section briefly describes these executive pay trends and their implications for both implicit and explicit RPE.

The 1980s and 1990s witnessed explosive growth in U.S. public company executive pay ${ }^{45}$ and a transformative shift away from an emphasis on salary and short-term, accounting-based incentives in favor of longer-term, equity-based pay. ${ }^{46}$ In part, this transformation was a response to criticism from economists, such as Michael Jensen and Kevin Murphy, who chided companies for providing insufficient performance-based incentives and paying executives like "bureaucrats." ${ }^{47}$ However, tax and accounting rules played major roles as well. ${ }^{48}$ The new equity-based compensation consisted primarily of stock options that rewarded executives for increases in their companies' share prices and, to a lesser extent, time-vested restricted stock grants that provided shares to executives who remained with their companies for the typical three- or four-year vesting period. ${ }^{49}$ By $2000,70 \%$ of senior executive pay at 350 large U.S.

${ }^{44}$ See id. at 405-08 (detailing rise of RPE compensation in 2000s).

45 The average compensation of the CEOs of large U.S. public companies increased in real terms (adjusting for inflation) by 500\% or more between 1975 and 2000. See Xavier Gabaix \& Augustin Landier, Why Has CEO Pay Increased So Much?, 123 Q.J. ECON. 49, 51 (2008); see also Carola Frydman \& Raven E. Saks, Executive Compensation: A New View from a Long-Term Perspective, 1936-2005, 23 REV. FIN. STUD. 2099, 2107 (2010).

46 Frydman \& Saks, supra note 45, at 2107.

47 See Michael C. Jensen \& Kevin J. Murphy, Performance Pay and Top-Management Incentives, 98 J. PoL. ECON. 225, 226 (1990); Michael C. Jensen \& Kevin J. Murphy, CEO Incentives-It's Not How Much You Pay, But How, HARV. Bus. ReV., May-June 1990, at 138, 138.

48 Prior to 2006, U.S. financial accounting rules strongly favored the use of the conventional, at-the-money stock options that are described in the following note over other forms of pay. Unlike all other forms of pay, companies were not required to recognize on their financial statements any compensation expense for these options at any time. See David I. Walker, The Law and Economics of Executive Compensation: Theory and Evidence, in Research Handbook on the Economics of Corporate Law 232, 238 (Claire A. Hill \& Brett M. McDonnell eds., 2012). In addition, a tax rule enacted in 1993, I.R.C. $\S 162(\mathrm{~m})$, limited corporate tax deductions for senior executive pay to $\$ 1$ million per executive per year but made an exception for performance-based pay, which included these stock options. See $i d$. at 239. It is generally believed that $\S 162(\mathrm{~m})$ contributed to the dramatic increase in the use of stock options and other forms of performance-based executive pay in the 1990s. See Gregg D. Polsky, Controlling Executive Compensation Through the Tax Code, 64 WASH. \& LeE L. Rev. 877, 906 (2007) ("The enactment of $\S 162(\mathrm{~m})$ provides an excuse for the colluding parties to engage in significant restructuring of compensation arrangements all in the name of preserving corporate deductions.").

49 Stock options provide the holder with a right, but no obligation, to purchase shares at a predetermined exercise price. Conventional compensatory stock options have a fixed exercise price set equal to the market price of the company's shares on the date of the grant (known as an at-the-money option); vest and become exercisable over some period, typically three to 
companies consisted of a combination of restricted stock and options, and most of that compensation took the form of options. ${ }^{50}$

While short-term bonuses were sometimes based on accounting performance vis-à-vis that of peers and so included explicit RPE, this was rarely the case for restricted stock grants and almost never the case for stock options. ${ }^{51}$ This was not ideal. It was widely recognized that purely time-vested restricted stock and conventional stock options rewarded executives for market rises even if firmspecific performance lagged the market and also exposed executives to market risk over which they had no control. In other words, these pay instruments lacked RPE. Holmstrom and other theorists had explained that the efficiency of pay could be improved by factoring out market risk and focusing rewards more closely on own-firm performance, ${ }^{52}$ and practice-oriented commentators proposed a means for doing so: indexing the exercise price of options to the market or to a basket of stocks including peer firms. ${ }^{53}$ But for a variety of tax and accounting reasons, indexation of options did not happen. ${ }^{54}$ So by the year

five years following grant; are nontransferable; and expire after ten years. Walker, supra note 48 , at 237. Time-vested restricted stock is typically awarded to an executive at no explicit cost. Id. If the executive remains with her company through the vesting period, the stock becomes owned outright. If the executive leaves prior to vesting, the stock must be returned. The stock may not be transferred or hypothecated in the interim. Id. Restricted stock units ("RSUs") are economically identical but represent a promise to deliver stock on the vesting date rather than an actual delivery of contingently owned stock. Id. Vesting details vary but typically involve ratable vesting over a period of three to five years following grant. $I d$. I use the term "restricted stock" in this Article to refer both to conventional restricted stock and RSUs.

${ }^{50}$ See David I. Walker, Evolving Executive Equity Compensation and the Limits of Optimal Contracting, 64 VAND. L. REV. 611, 633 (2011).

${ }^{51}$ Level 3 Communications was one exception. In the 1990s, Level 3 adopted a stockoption plan that indexed option-exercise prices to variations in the S\&P 500. See Joann S. Lublin, Pay for Outperforming: James Crowe, Chief of Level 3 Communications, Makes the Case for Linking Stock Options to Market-Beating Gains, WALl StReET J., Apr. 6, 2000, at R8.

52 See Holmstrom, supra note 7, at 334-39.

53 See Alfred Rappaport, New Thinking on How to Link Executive Pay with Performance, Harv. Bus. ReV., Mar.-Apr. 1999, at 91, 93-97.

${ }^{54}$ Prior to 2006, U.S. financial accounting rules strongly favored the use of conventional, at-the-money stock options over other forms of pay. Companies were not required to recognize any compensation expense for these options at any time. Indexed options, by contrast, had to be expensed, and the expense had to be adjusted in each accounting period for fluctuations in share price. See Walker, supra note 48, at 238. Although the accounting rules for equity-based pay were rationalized beginning in 2006, § 409A of the Internal Revenue Code, which was enacted in 2004, essentially precludes the issuance of indexed options today by imposing a $20 \%$ penalty tax on the income arising from such options. See id. at $239-40$. 
2000, only a small fraction of U.S. public company executive pay included any explicit RPE. 55

To be sure, relative performance evaluation could have factored into executive pay contracts implicitly. Increases in salary, bonus targets, and equity grants might have been based, in part, on the prior year's (or years') performance relative to peer firms. However, the evidence of implicit RPE in executive pay contracts during this period is modest. For example, Rick Antle and Abbie Smith examined executive pay at thirty-nine companies within three industries between 1947 and 1977 and found only weak evidence of implicit RPE. ${ }^{56}$ Robert Gibbons and Kevin Murphy analyzed CEO pay at over 1000 companies between 1974 and 1986 and found evidence that RPE was used implicitly in compensation and retention decisions; however, they also found that performance was more likely to be gauged relative to broad market movements than to industry-specific performance. ${ }^{57}$ Writing in 2003, John Core, Wayne Guay, and David Larcker concluded that there was little evidence that executive bonuses included RPE. ${ }^{58}$

This situation changed dramatically in the early 2000 s as performance awards replaced stock options as the single largest element of most senior executive pay packages. ${ }^{59}$ Performance awards include performance-based option plans and long-term cash incentive plans that are performance based, but most performance awards consist of performance shares. ${ }^{60}$ Performance shares are essentially restricted stock grants that vest based on achievement of time and performance hurdles. Typically, performance share plans cover three-year performance periods and allow for the delivery of a variable number of shares associated with threshold, target, and maximum achievement of performance

55 See Walker, supra note 43, at 405.

${ }^{56}$ See Rick Antle \& Abbie Smith, An Empirical Investigation of the Relative Performance Evaluation of Corporate Executives, 24 J. ACCT. RES. 1, 3 (1986) (finding some evidence of $\mathrm{RPE}$ at sixteen of thirty-nine companies and describing their results as "mixed").

57 See Robert Gibbons \& Kevin J. Murphy, Relative Performance Evaluation for Chief Executive Officers, 43 Indus. \& LAB. Rel. Rev. (Special ISsue) 30-S, 38-S (1990). As discussed supra Section II.A, benchmarking against broad market movements is less likely to encourage competition than benchmarking against a select group of peer companies.

58 See John E. Core, Wayne R. Guay \& David F. Larcker, Executive Equity Compensation and Incentives: A Survey, Fed. Res. Bank N.Y. Econ. Pol. ReV., Apr. 2003, at 27, 38.

59 See Walker, supra note 43, at 405 (noting that performance-based equity pay increased by $350 \%$ between 2001 and 2012).

60 See J. Carr Bettis et al., Performance-Vesting Provisions in Executive Compensation, 66 J. ACCT. \& ECON. 194, 197 (2018) (analyzing compensation at 1000 large companies and finding that $97 \%$ of companies utilizing performance-based equity pay issued performance shares while only $8 \%$ issued performance-based options). To be clear, performance-based options are not options with indexed exercise prices but are options that vest on the achievement of performance thresholds as well as time. 
goals. ${ }^{61}$ Beyond this, however, performance share design details vary widely. Plans may include absolute (firm-specific) performance goals, relative performance goals, or (increasingly) some combination of the two. ${ }^{62}$ The goals may be based on accounting results (e.g., earnings per share), market results (e.g., total shareholder return), ${ }^{63}$ or other more idiosyncratic metrics (e.g., safety performance). ${ }^{64}$ Where RPE is explicitly invoked, performance may be measured relative to a broad market index (e.g., the S\&P 500), an industryspecific index, or a select group of peer firms. ${ }^{65}$

Performance awards now account for the majority of the long-term incentives provided to U.S. public-company senior executives. In an analysis of 2017 CEO compensation at the largest 300 U.S. public companies, executive pay consultants Korn Ferry found that performance awards accounted for $55 \%$ of long-term incentives at the median, with conventional options and time-vested restricted stock each accounting for about $22.5 \% .{ }^{66}$

The explicit use of RPE has mushroomed as companies have embraced performance awards. Because performance awards can include multiple goals, it is difficult to pinpoint the exact economic significance of RPE in executive pay contracts, but the growth is unmistakable. Rebecca DeSimone finds that the fraction of companies in the ISS Incentive Lab database that included explicit RPE metrics in long-term compensation awards increased from less than $15 \%$ during the height of the late 1990 s/early 2000 s option boom to over $50 \%$ by

61 See FW COOK, 2018 TOP 250 REPORT 17 (2018), https://www.fwcook.com/content /documents/Publications/11-7-18_FWC_2018_Top_250_Final.pdf [https://perma.cc/W5DZHPW4] (showing that $91 \%$ of surveyed companies reported measuring performance over a three-year period). Although most plans provide for threshold, target, and maximum performance targets, the number of shares delivered is generally a continuous function with interpolation between these discrete targets. See Walker, supra note 43, at 412.

62 See Bettis et al., supra note 60, at 198.

63 Total shareholder return is the sum of share price appreciation and dividends paid per share over some period, expressed as a percentage of share price at the beginning of the period. Total Shareholder Return (TSR), INVESTOPEDIA, https://www.investopedia.com/terms/t /tsr.asp [https://perma.cc/NC9W-2L8Y] (last updated June 25, 2019).

${ }^{64}$ See Bettis et al., supra note 60, at 200.

65 See John Bizjak et al., The Role of Peer Firm Selection in Explicit Relative Performance Awards 15 (Apr. 6, 2019) (unpublished manuscript), https://papers.ssrn.com/sol3 /papers.cfm?abstract_id=2833309 [https://perma.cc/8VE3-TRZZ].

${ }^{66}$ Press Release, Tracy Kurschner, Pub. Relations Manager, Korn Ferry, Cash Is Not King-CEO Annual Pay Raises Hit New Low with Smallest Increase in 6 Years (May 4, 2017), https://ir.kornferry.com/news-releases/news-release-details/cash-not-king-ceo-annual -pay-raises-hit-new-low-smallest [https://perma.cc/M8BB-VXS7]; see EQUILAR, EXECUTIVE Long-Term InCEntive Plans: PAy FOR Performance Trends 8 (2017) (finding that $87 \%$ of S\&P 500 companies granted at least one performance award in 2015). 
$2014 .{ }^{67}$ Similarly, executive pay consultant Equilar reports that the percentage of S\&P 500 companies issuing explicit RPE awards to their CEOs increased from $42 \%$ to $57 \%$ between 2011 and 2015 alone. ${ }^{68}$

To be sure, some companies may adjust discretionary compensation based on relative performance in addition to or instead of incorporating RPE explicitly into equity pay instruments. But given the popularity of explicit RPE and the push from proxy advisory firms and institutional investors for RPE described in the next section, it seems likely that explicit RPE dominates implicit RPE in today's executive pay landscape.

\section{Why Did Companies Embrace Explicit RPE in the 2000s?}

This Article is primarily concerned with the current widespread adoption of RPE and its relationship with common ownership. Thus, to some extent, the reason that companies adopted explicit RPE-based awards is irrelevant. Nonetheless, a brief look at why companies embraced RPE may help us understand the contours and likely persistence of today's common pay practices.

While certainly not perfectly clear, the largest factor in the widespread adoption of explicit RPE metrics in long-term executive pay arrangements was likely the move away from stock options in the early 2000s. ${ }^{69}$ Encouraged by tax and accounting preferences, U.S. public companies embraced stock options as the primary long-term incentive pay vehicle in the $1990 \mathrm{~s} .{ }^{70}$ In theory, stock options could have been designed to include RPE. The exercise price of options could have been indexed to a measure of industry or market performance, such that payouts would be based on firm-specific performance, but tax and accounting rules effectively prevented companies from adopting indexed options. $^{71}$

However, reliance on options declined precipitously in the 2000s with the burst of the dot-com bubble and the end to irrational exuberance and with the 2004 (effective 2006) revision of U.S. accounting rules to level the playing field between options and other forms of compensation. ${ }^{72}$ In addition, stock options

${ }^{67}$ See DeSimone, supra note 6, at 34. The ISS Incentive Lab database provides detailed information on executive pay arrangements since 1998 at approximately 1200 of the largest U.S. public companies. Id. at 15.

68 EQUILAR, supra note 66, at 8.

69 Walker, supra note 50, at 634-41 (discussing various factors influencing shift from option to stock compensation).

70 As discussed supra note 48, prior to 2006, conventional compensatory stock options bore no cost from an accounting perspective. Further, in 1992 Congress amended the tax rules to deny deductions for senior executive pay in excess of $\$ 1$ million per executive per year except for certain performance-based pay. Stock options satisfied the performance-pay exception. Walker, supra note 48, at 239.

71 See supra note 54.

72 See Walker, supra note 50, at 636, 639-41. 
took on a negative connotation in the wake of options-related scandals at Enron, WorldCom, and Tyco in the early 2000s and with the option backdating scandal that followed a few years later. ${ }^{73}$ With options out of favor, companies turned to other equity-based tools, including restricted stock, to provide medium- to longterm incentives. But restricted stock had its own credibility problem. By this point, shareholder advocates and proxy advisory firms had thoroughly embraced the position that executive pay should be linked closely with firm performance, and conventional, time-vested restricted stock-sometimes derisively referred to as "pay for pulse" - was not viewed as being sufficiently performance-based for many stakeholders. ${ }^{74}$ However, performance-vesting conditions could be added to restricted stock without triggering any adverse tax or accounting consequences, and, of course, this is what companies did, increasingly, beginning in the 2000s. ${ }^{75}$

To be sure, there was no inherent requirement that performance conditions placed on restricted stock be relative performance conditions. The adoption of absolute performance conditions may have been sufficient for many stakeholders. But once performance conditions were dictated and the accounting and tax obstacles to the adoption of RPE were eliminated, it is perhaps not surprising that many companies would embrace RPE as consistent with compensation theory and common sense.

An additional push for RPE came from two sources. First, the large institutional investors (who are also the largest common owners and might be expected to disfavor RPE if compensation is a mechanism for dampening competition) at least superficially promoted relative evaluation. ${ }^{76}$ Second, the

\footnotetext{
73 See id. at 637-38.

${ }^{74}$ See, e.g., Simon Patterson \& David Bixby, Can RSUs Reduce Executive Pay Complexity?, PEARl MeYER (Dec. 2017), https://www.pearlmeyer.com/knowledge-share /ask-the-expert/can-rsus-reduce-executive-pay-complexity [https://perma.cc/L8SU-4ZPH] (noting investors' perception that time-vested restricted stock constitutes "paying for pulse").

${ }^{75}$ In addition, purely time-vested restricted stock did not satisfy the performance-based pay exception to I.R.C. $\S 162(\mathrm{~m})$ and thus was largely not deductible. Restricted stock with performance-vesting conditions was generally fully deductible. See Walker, supra note 43, at 407.

${ }^{76}$ BlackRock, for example, states that "[o]ur evaluation of equity compensation plans is based on a company's executive pay and performance relative to peers." BLACKROCK, PROXY Voting GUIDELINES FOR U.S. SECURITIES 11 (2019), https://www.blackrock.com /corporate/literature/fact-sheet/blk-responsible-investment-guidelines-us.pdf

[https://perma.cc/3WGL-2AV2]. In determining how to vote on executive "say on pay" proposals, Fidelity takes into account "[t]he alignment of executive compensation and company performance relative to peers." Fidelity, Proxy Voting Guidelines 6 (2019), https://www.fidelity.com/bin-public/060_www_fidelity_com/documents/Full-Proxy-

Voting-Guidelines-for-Fidelity-Funds-Advised-by-FMRCo-and-SelectCo.pdf [https://perma.cc/BE2N-RGYH]. Capital Group
} 
proxy advisory firms adopted executive pay guidelines that encouraged the use of RPE. For example, in its discussion of its approach to executive compensation analysis, proxy advisor Glass Lewis states: "[W]e believe executive compensation should be closely tied not to absolute or overall performance but rather to the company's track record of performance relative to its peers. Management should be especially rewarded for directing the company in a manner that outperforms its peers." 77

Moreover, the proxy advisory firms have explicitly incorporated RPE in their evaluation processes. Glass Lewis's proprietary pay-for-performance model is based on a comparison of executive compensation, total shareholder return, earnings-per-share growth, change in operating cash flow, return on equity, and return on assets at the target company and at a selected group of peer companies. $^{78}$

Similarly, the most influential proxy advisory firm, Institutional Shareholder Services ("ISS"), employs several tools for evaluating the relationship between executive pay and performance-three of which are based on relative performance. ${ }^{79}$ For example, their Relative Degree of Alignment measure determines a company's percentile rank over a three-year period among a group of peer firms for CEO pay and total shareholder return and then compares the two percentiles. ${ }^{80}$ Executives are overpaid by this measure when their CEO pay percentile exceeds their total shareholder return percentile. ${ }^{81}$ According to John Bizjak, Swaminathan Kalpathy, Zhichuan Frank Li, and Brian Young, compensation consultants report that companies often adopt explicit RPE-based awards when ISS raises questions about the relationship between pay and company performance. ${ }^{82}$

prefer[s] a significant portion of management's compensation to come in the form of equity stakes tied to long-term value creation for all shareholders. It is important, however, that such compensation be designed not merely to reward a "rising tide" in either the market or a specific industry that cannot be fairly attributed to management skill or contribution.

Information on Capital Group's Policies and Disclosures, CAPITAL GROUP, https://www.capitalgroup.com/us/policies-and-disclosures.html (last visited Nov. 14, 2019).

77 Understanding Our Compensation Analysis, GLASs LEWIS, https://web.archive.org/web /20190226024258/http:/www.glasslewis.com/understanding-our-compensation-analysis/

[https://perma.cc/N9H8-56P5] (last visited Nov. 14, 2019) (click "Pay-for-Performance Analysis").

78 See id.

79 Institutional S'holders Servs., Pay-for-Performance Mechanics 5-7 (2019), https://www.issgovernance.com/file/policy/active/americas/Pay-for-PerformanceMechanics.pdf [https://perma.cc/F4W5-PFYE] (specifically, Relative Degree of Alignment, Multiples of Median, and Financial Performance Assessment).

${ }^{80}$ See id. at 5-6.

81 See id. at 5.

82 See Bizjak et al., supra note 65, at 23 n.24. 


\section{Avoidance of RPE Is Unlikely to Be a Mechanism by Which Common Owners Discourage Interfirm Competition}

It is well understood that the ownership of U.S. equities has become increasingly concentrated in the hands of institutional investors in general and in the hands of index funds specifically. ${ }^{83}$ Given the objective of owning the market, it is not surprising that index investors have amassed large stakes in multiple companies within an industry. To be sure, the significance of this common ownership and even how it is best measured is controversial, ${ }^{84}$ but by any measure, the incidence and degree of common ownership has increased significantly over the last twenty-five years. ${ }^{85}$

Undoubtedly less well recognized is the transformation of executive pay over the same period - chiefly the replacement of options at many companies with performance shares and the inclusion of explicit RPE metrics in many of these awards. ${ }^{86}$ In an influential article, Elhauge suggests that increasing institutional investor common ownership, which he calls horizontal shareholding, can help explain the shift toward compensation schemes-principally stock optionsthat reward executives for industry or market performance rather than for firmspecific performance alone. ${ }^{87}$ While this might have been an accurate description of the executive pay landscape in the year 2000, this line of argument ignores the dramatic increase in the use of explicit RPE metrics in executive pay arrangements over the last twenty years, as documented above. ${ }^{88}$ It is simply no longer true as an empirical matter.

The upshot, however, is that the major secular trends in share ownership and executive pay design run exactly counter to the hypothesis that compensation design might serve as a mechanism linking common ownership to reduced interfirm competition. As displayed in Figure 1 below, both common ownership and the use of explicit RPE have increased substantially over the last twenty to twenty-five years - exactly opposite of what one would expect if common owners were using compensation design to discourage (or not encourage) competition.

\footnotetext{
${ }^{83}$ See supra text accompanying notes 14-16.

${ }^{84}$ See supra text accompanying notes 23-25.

${ }^{85}$ See supra text accompanying notes 14-16.

${ }^{86}$ See Walker, supra note 43, at 396.

${ }^{87}$ See Elhauge, supra note 1, at 1278-81.

${ }^{88}$ See supra text accompanying notes 59-68.
} 
Figure 1. Increases in Company Common Ownership and Use of Explicit RPE. ${ }^{89}$

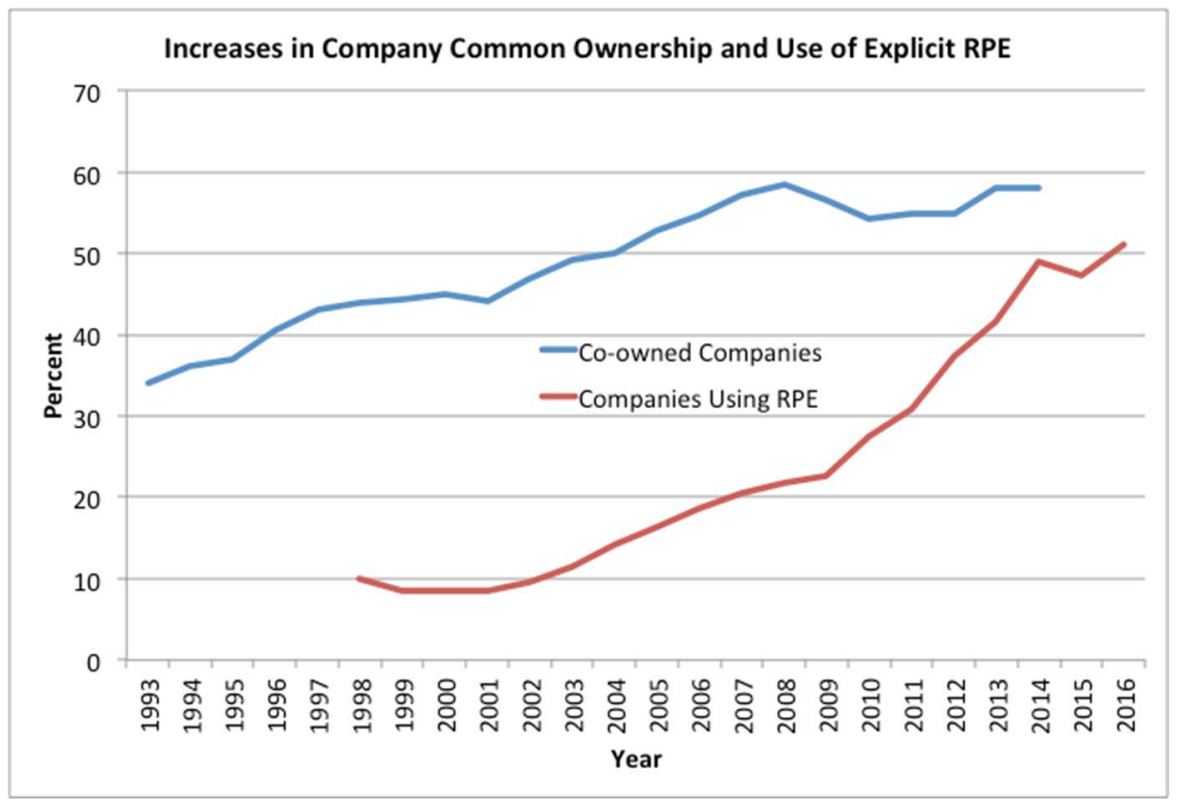

This macro-level evidence is also inconsistent with the hypothesized passive or "do nothing" mechanism proposed by Azar, Schmalz, and Tecu. ${ }^{90}$ Recall that the idea here is that, unlike an undiversified owner who might actively encourage competition, a common owner might simply refrain from active encouragement, in which case executives will tend to avoid taking personally costly actions to compete and simply enjoy the quiet life. ${ }^{91}$ But adopting RPEbased compensation instruments is the opposite of doing nothing. Given the potential to boost pay by outcompeting peer firms, it would be costly for RPEcompensated executives to refrain from competition.

Of course, this macro-level evidence is not conclusive. It is possible that while the use of RPE is increasing generally among U.S. companies, companies in

${ }^{89}$ Common ownership data is based on Liang, supra note 6, at 30, and represents the fraction of ExecuComp companies that share at least one common blockholder with another company in the same industry. Compustat's ExecuComp database compiles senior executive pay data from proxy statements of approximately 2200 of the largest U.S. public companies each year. See DeSimone, supra note 6, at 10. RPE-use data is based on DeSimone, supra note 6 , at 34 , and represents the fraction of ISS Incentive Lab companies that issue at least one long-term performance award incorporating an RPE metric each year.

90 Azar, Schmalz \& Tecu, supra note 3, at 1556-58.

${ }^{91}$ See id. 
industries with high levels of common ownership avoid the use of RPE or design RPE in such a way as to minimize incentives to compete. But, as discussed in the following paragraphs, the evidence does not support these ideas either.

Let us begin with the latter idea - that RPE might be designed in such a way as to create an appearance of performance measurement vis-à-vis peers (that might satisfy the proxy advisory firms and other stakeholders) but to actually avoid fostering intense competition..$^{92}$ As noted above, choice of peer group is a key RPE design issue. ${ }^{93} \mathrm{RPE}$ may be based on a select group of peer companies, on a preexisting industry-specific index, or on a broad market index. ${ }^{94}$ While the use of a select peer group benchmark creates incentives to undermine peer performance, this is not the case for RPE based on a broad market index. As discussed above, undermining the performance of one's direct competitors - by taking market share or through other means - would have an insignificant effect on relative company performance if company performance is gauged relative to the S\&P 500 or the Russell 3000 index. ${ }^{95}$ The impact of benchmarking against an industry-specific index would be somewhere in between, likely depending on the number of companies in the index.

So one way of incorporating RPE without encouraging intense competition would be through selection of a broad market index as the "peer" group. Thus, to the extent that commonly owned companies utilize explicit RPE, the compensation-mechanism hypothesis would predict that these companies would adopt broad market indices as benchmarks. However, while all three approaches are observed in practice, the most common approach is to employ a select group of peer firms, typically ten to twenty companies. ${ }^{96}$ Bizjak, Kalpathy, Li, and Young find that of the $47 \%$ of ISS Incentive Lab companies that issued RPEbased awards in $2015,60 \%$ employed a select group of peer firms, while $22 \%$ employed a broad market index. ${ }^{97}$ The emphasis on select peer firm benchmarking does not seem consistent with stifling competition.

This is not to suggest that encouraging or discouraging interfirm competition is the sole or even primary concern in designing RPE-based incentives. Benchmarking based on a broad market index performs a different economic function than benchmarking based on direct peer performance. The former

${ }^{92}$ To be sure, ISS and Glass Lewis gauge performance relative to a select peer group of companies, but it seems likely that companies would get some credit for RPE based on a broad market index. See supra text accompanying notes 77-81.

93 See supra Section II.A.

94 See supra text accompanying note 65.

95 See supra Section II.A.

96 Bizjak, Kalpathy, Li, and Young find that, for ISS Incentive Lab companies that use a select peer group, the average (median) number of companies in the group is 16.6 (15) and that the number of peers at the 25th and 75th percentiles are 11 and 20. See Bizjak et al., supra note 65 , at 15 .

97 See id. 
approach filters out broad market movements - such as the run up in the entire stock market during the early years of this decade-while the latter approach filters out market trends and industry trends. Each has its advantages, but the heavy use of select peer groups does not support the idea that pay design serves as a mechanism for discouraging competition.

As discussed above, Schmalz argues that RPE-based compensation encourages product market competition when performance is measured based on company value creation, since such metrics encourage competition over market share and output, but that RPE discourages competition when based on margins, since margins are generally improved by restricting output. ${ }^{98}$ All else equal, common owners would prefer their portfolio companies to restrict output and push up prices. So it is feasible that companies might embrace RPE (and satisfy the proxy advisory firms and other stakeholders) while selecting RPE metrics that do not encourage fierce product market competition between commonly owned peer firms.

Again, both types of RPE metrics are encountered in practice, but the most common metric employed, by far, is total shareholder return - and this metric falls squarely within the value creation/pro-competition camp. Bizjak, Kalpathy, $\mathrm{Li}$, and Young find that $88 \%$ of ISS Incentive Lab companies issuing RPE awards in 2015 employed a total shareholder return metric. ${ }^{99}$ Again, heavy reliance on total shareholder return metrics does not seem to be consistent with discouraging competition through executive pay design.

Another possibility is that companies in industries with high levels of common ownership shun RPE relative to companies in other industries or that these companies tend to employ weaker or competition-dampening RPE structures. This brings us to the empirical literature addressing the relationship between common ownership and RPE use, which is considered in the next section.

\section{E. A New Challenge to the Empirical Evidence on the Association Between Common Ownership and the Use of RPE}

The empirical evidence linking common ownership to reduced use of RPE is actually relatively modest. To date, four working papers investigate the link between common ownership and RPE, per se: the 2016 version of AEGS's paper (later revised to focus on the sensitivity of executive wealth to performance rather than RPE) ${ }^{100}$ and papers by Rebecca DeSimone, Heung Jin Kwon, and Max Liang. ${ }^{101}$ AEGS and Liang find a negative relationship between common ownership and RPE, Kwon finds a positive relationship, and DeSimone finds no evidence that executive compensation design is a mechanism used by common

\footnotetext{
98 See Schmalz, supra note 41.

99 See Bizjak et al., supra note 65, at 15.

100 See generally AEGS (2016), supra note 5; AEGS (2018), supra note 5.

101 See generally DeSimone, supra note 6; Kwon, supra note 6; Liang, supra note 6.
} 
owners to dampen competition. ${ }^{102}$ So one issue with the empirical evidence is that the results of the few studies we have are mixed. Other problems are methodological.

Like the Azar et al. airline and banking papers, several of these papers use the MHHI to determine common-owner incentives. ${ }^{103}$ As noted above, this methodology has been criticized extensively, and I will not repeat those criticisms here. ${ }^{104}$ Instead, this Article highlights a separate and serious methodological concern with the other side of the equation: the measurement of executive incentives. In short, the primary empirical strategy employed in these papers is appropriate for identifying implicit RPE but not explicit RPE. If, as I argued above in Part II, explicit RPE dominates implicit RPE in modern executive pay arrangements, this is a fatal analytical flaw.

Each of these papers uses ExecuComp's total compensation variable ("TDC1") as the primary measure of executive compensation. ${ }^{105}$ AEGS's strategy is to determine the sensitivity of TDC1 to own-firm and to rival-firm performance. ${ }^{106}$ They predict (and find) that where common ownership is high, executives are paid relatively more for rival-firm performance and less for ownfirm performance. ${ }^{107}$ Liang's strategy is similar. ${ }^{108}$ Kwon also uses TDC1 as his primary compensation variable but estimates pay-for-performance elasticities ${ }^{109}$-rather than sensitivities - and finds that greater common

102 See AEGS (2016), supra note 5, at 54; DeSimone, supra note 6, at 2; Kwon, supra note 6, at 34; Liang, supra note 6, at 25.

103 See AEGS (2016), supra note 5, at 14; Kwon, supra note 6, at 2. DeSimone recognizes and discusses the limitations of the MHHI, but she employs it to demonstrate that the results of AEGS (2016) and Kwon are not robust. See DeSimone, supra note 6, at 4. Liang employs a 5\% blockholder threshold in determining co-owned peers within three-digit SIC industries. Liang employs a $5 \%$ blockholder threshold in determining co-owned peers within three-digit SIC industries. See Liang, supra note 6, at 8-9.

104 See supra text accompanying notes 23-25; see also O'Brien \& Waehrer, supra note 23, at 596-97; Patel, supra note 24, at 300-18. From a theoretical point of view, Rock and Rubinfeld note that ISS makes no distinction between companies with high and low MHHI in its guidelines favoring RPE and argue that this makes it unlikely that there would be significant variation in the use of RPE based on the MHHI. See Rock \& Rubinfeld, supra note 25 , at $249-50$.

105 See AEGS (2016), supra note 5, at 15; DeSimone, supra note 6, at 10; Kwon, supra note 6, at 8-9, 42; Liang, supra note 6, at 9.

106 See AEGS (2016), supra note 5, at 19-22, 57.

107 See id. at 32.

108 See Liang, supra note 6, at 1 (finding that CEO TDC1 is positively related to stock price performance of industry peers with common blockholders).

109 See Kwon, supra note 6, at 8. Pay-for-performance elasticity refers to the percentage change in compensation relative to a percentage change in firm value; sensitivity refers to the dollar change in compensation relative to a dollar change in firm value. But see DeSimone, 
ownership is associated with greater use of RPE. ${ }^{110}$ DeSimone replicates each of these approaches while making various methodological improvements and finds no significant relationship between common ownership and use of RPE. ${ }^{111}$

ExecuComp variable TDC1 is a measure of aggregate compensation delivered to a senior executive in a given year. ${ }^{112}$ It includes salary; annual bonus; and long-term, non-equity compensation actually paid - but for the largest portions of executive pay, that is, long-term equity compensation, TDC1 is an ex ante estimate. ${ }^{113}$ Conventional stock options are valued based on the Black-Scholes-Merton ("BSM") option-pricing formula, with certain adjustments to reflect the idiosyncrasies of compensatory options. ${ }^{114}$ More complex performance awards are valued using BSM or, more commonly, Monte Carlo simulations. ${ }^{115}$

The use of TDC1 as a compensation measure and the strategy of determining the sensitivity of TDC1 to own-firm and rival-firm performance are appropriate for identifying implicit use of RPE but are inappropriate for analyzing explicit RPE. Imagine first a compensation package consisting only of salary and a discretionary cash bonus. Compensation might be awarded based on firmspecific performance only, or to some degree, upon relative performance. The latter would constitute implicit RPE, and measuring the sensitivity of total compensation awarded to own-firm performance and to rival-firm performance would be a reasonable way to gauge the extent of the implicit use of RPE in setting pay.

But now consider pay packages that consist primarily of long-term, equitybased pay. To simplify, let us suppose that compensation consists solely of a conventional stock option or, alternatively, of a performance share grant where the number of shares delivered is a function of three-year total shareholder return relative to that of a dozen peer companies. TDC1 in each case would equal the

\footnotetext{
supra note 6, at 14 (criticizing Kwon's use of elasticities from both theoretical and empirical perspectives).

110 See Kwon, supra note 6, at 6.

111 See DeSimone, supra note 6, at 12-17.

112 Executive pay data collected in the ExecuComp database is based on proxy statement disclosures, which generally include pay data for a public company's CEO, CFO, and three most highly compensated executives other than the CEO and CFO. The composition of this senior executive group has varied slightly over time. See Walker, supra note 48, at 245-46.

113 See ExecuComp Data Definitions, Wharton Res. DATA SERvs., https://wrdswww.wharton.upenn.edu/documents/960/Execucomp_Data_Definitions.pdf (last visited Nov. 14, 2019) (defining TDC1 as "[t]otal compensation comprised of the following: Salary, Bonus, Other Annual, Total Value of Restricted Stock Granted, Total Value of Stock Options Granted (using Black-Scholes), Long-Term Incentive Payouts, and All Other Total").

114 Most significantly, an experience-based estimated holding period is used to value compensatory options rather than the expiration period used in valuing tradable options. See Walker, supra note 43, at 423.

115 See Bizjak et al., supra note 65, at 5 n.9.
} 
ex ante value of the grant. Regressing TDC1 against own-firm and rival-firm performance would determine the implicit use of RPE in setting the size of these equity grants but tells us nothing about their explicit RPE characteristics. In this example, the explicit RPE characteristics would likely be much more important in terms of incentive creation than variations in the size of the awards. The relative total shareholder return award based on selected peer performance has strong explicit RPE features, while the conventional stock option lacks explicit RPE.

It is completely possible, in fact, that companies that adopt long-term pay instruments incorporating strong, explicit RPE metrics might reduce the extent to which they adjust discretionary bonuses or salary awards for relative company performance. It is possible, in other words, that variations in implicit RPE determined in this fashion might run opposite to variations in total explicit and implicit RPE. ${ }^{116}$ At the least, there may be a tradeoff between identifying implicit and explicit RPE. If so, a strategy focusing on implicit RPE might be appropriate for analysis of data from the period in which explicit RPE was generally lacking in U.S. executive pay but inappropriate for analysis of data from the early 2000s on, when explicit RPE became central.

DeSimone recognizes that TDC1 incorporates only the ex ante value of compensation and thus fails to fully reflect executive incentives. ${ }^{117}$ Nonetheless, she replicates (and improves upon) AEGS's and Kwon's approaches and finds no relationship between common ownership and the use of RPE. ${ }^{118}$ DeSimone goes on, however, to use ISS Incentive Lab data to test the relationship between common ownership (employing still admittedly flawed methodology) and the explicit use of RPE. ${ }^{119}$ She finds that the probability that a company utilizes an explicit RPE-based award and a measure of the size of such awards are either unrelated to or positively associated with the degree of common ownership within an industry. ${ }^{120}$

In sum, the empirical evidence linking common ownership to reduced use of RPE is weak at best, is subject to serious methodological criticism, and does not support the claim that executive pay design is a mechanism for linking common ownership to reduced competition between companies. Given the secular trends

116 AEGS and Kwon both note that they run alternative regressions using ExecuComp variable TDC2 as the measure of compensation and that their results are unchanged. AEGS (2016), supra note 5, at $31 \mathrm{n} .5$; Kwon, supra note 6, at 9 n.4. However, the only difference between TDC1 and TDC2 is that the latter replaces ex ante option values with realized values. TDC2 does not include the ex post value of performance shares, and the large majority of explicit RPE awards are performance share awards. See ExecuComp Data Definitions, supra note 113, at 48 (defining TDC2 as "[t]otal compensation (Salary + Bonus + Other Annual + Restricted Stock Grants + LTIP Payouts + All Other + Value of Options Exercised”).

117 See DeSimone, supra note 6, at 12, 17-18.

118 See id. at 12.

119 See id. at 15.

120 See id. at 2, 21-23. 
of increasing common ownership and increasing reliance on explicit RPE in executive pay contracts, as well as the particular design features of RPE-based awards, the lack of strong RPE-based evidence supporting the compensation mechanism is not surprising.

\section{COMMON OWNERSHIP AND THE SENSITIVITY of EXeCutive Wealth to OWN-Firm PERFormance}

AEGS have revised their empirical strategy in the most recent version of their paper. Before, they investigated the association between common ownership and the sensitivity of executive pay to own-firm and rival-firm performance; ${ }^{121}$ now, they investigate the relationship between common ownership and the sensitivity of executive wealth to own-firm performance. ${ }^{122}$ The reason for this change is their recognition that annual "flow" compensation, even including long-term elements, represents only a fraction of executive incentives. ${ }^{123}$ They note that executives' vested and unvested stock and option holdings are generally more significant than current pay in creating incentives, including incentives to compete hard with rival firms. ${ }^{124}$ Their revised hypothesis is that greater common ownership leads to less pressure to implement high-powered incentives, as measured by the sensitivity of executive wealth to own-firm performance. ${ }^{125}$ Unfortunately, as described below, there are serious conceptual and empirical difficulties with a wealth-sensitivity approach that cause it to be less promising than an RPE-based approach.

\section{A. The Revised AEGS Approach in Detail}

In the latest version of their working paper, AEGS employ various measures of the sensitivity of executive wealth to own-firm performance ("WPS") as a dependent variable and various measures of common ownership and other controls as independent variables. ${ }^{126}$ In most specifications they find a statistically significant negative association between WPS and the degree of common ownership within an industry. ${ }^{127}$ They also conduct a difference-indifferences analysis based on BlackRock's 2009 acquisition of Barclays Global Investors ("BGI"), which consolidated the ownership of two very large and formerly distinct investment portfolios. ${ }^{128}$ Examining data for three years

\footnotetext{
121 AEGS (2016), supra note 5, at 5.

122 AEGS (2018), supra note 5, at 3.

123 See id. at 3.

${ }^{124} \mathrm{Id}$.

125 Id. at 2-3.

126 See id. at $22-24$.

127 See id. at 22.

128 See id. at 25. In 2008, BlackRock was the sixth largest and BGI the largest global asset manager. Table: The P\&I/Watson Wyatt World 500, Pensions \& InV. (Oct. 5, 2009, 1:00
} 
following the acquisition compared to three years prior, they find that, relative to other industries, WPS declines when the common ownership within an industry increases as a result of this consolidation. ${ }^{129}$ As a possible mechanism for their findings, AEGS suggest:

The simplest mechanism is that the absence of a large active blockholder (with a strong interest in the target firm and without interests in competitors) is associated with reduced efforts to design high-powered managerial incentives. In other words, common owners need not actively design flat incentives; they may merely fail to design steep ones the way a non-common owner would. ${ }^{130}$

\section{B. Concerns with the Revised AEGS Approach}

It is certainly true that an executive's incentives depend on her equity portfolio as well as on current compensation instruments. And it is also true that evidence of a negative association between WPS and common ownership is consistent with evidence of a negative association between RPE and common ownership. ${ }^{131}$ But the shift from an RPE-based approach to a WPS-based approach in evaluating the relationship between common ownership and executive incentives is troubling for several reasons. ${ }^{132}$

First, while it is also true that a low wealth-to-performance sensitivity would tend to discourage (or more precisely, not encourage) executives to compete hard with rival firms, a low WPS also discourages executives from working hard generally or from taking steps to increase profitability through noncompetitive channels, such as lobbying for more favorable industry-specific tax rules. The idea that common owners would want to provide low-powered incentives in order to discourage competition seems like tossing the baby out with the bathwater and is certainly inconsistent with the stated objectives of the largest institutional investors. ${ }^{133}$ Second, while companies clearly do manage executive incentives through the use and design of annual bonus schemes and equity-based pay, they largely lack the ability to fine-tune or adjust WPS in the short to medium term. ${ }^{134}$ Thus, the results of AEGS's BlackRock/BGI merger analysis

AM), https://www.pionline.com/article/20091005/INTERACTIVE/910019997/table-the-p-iwatson-wyatt-world-500 [https://perma.cc/E9UQ-484G].

129 See AEGS (2018), supra note 5, at 27.

${ }^{130} I d$. at 4 . AEGS do not directly test for the absence or presence of large, unconflicted blockholders.

131 See id. at 3, 7.

132 Hemphill and Kahan raise several methodological issues related to the revised AEGS paper. They note, for example, that AEGS ignore noninstitutional blockholders, which may lead to errors in the MHHI calculation. Hemphill \& Kahan, supra note 28 (manuscript at 19).

133 See infra Section III.B.1.

${ }^{134}$ See infra Section III.B.2. 
are particularly difficult to square with the theory. ${ }^{135}$ Third, the shift to a WPSbased approach presents methodological challenges that AEGS may not have addressed-specifically, the challenges in determining WPS associated with complex performance share awards incorporating multiple absolute and relative performance metrics. ${ }^{136}$

\section{Low WPS Is Inconsistent with Common-Owner Preferences}

First, while one can imagine that large common owners in concentrated industries, such as the airline industry or banking sector, ${ }^{137}$ might prefer collusion to competition and might prefer to avoid pay practices that encourage fierce competition, it seems much less plausible that preferences for collusion over competition would be so great that common owners would prefer weak incentives to powerful incentives generally. Of course, that is not exactly the claim. The claim is that common owners prefer and achieve marginally weaker executive incentives than noncommon blockholders, all else equal. ${ }^{138}$ Even so, it is unlikely that these preferences would be strong enough to translate into statistically significant results. Reducing pay-for-performance incentives simply seems too blunt an instrument for minimizing interfirm competition. At the same time that investors would be reducing incentives for interfirm competition, they would be reducing incentives for executives to work hard generally, including in ways that would not shift profits away from competitors but would increase overall industry profitability, such as through lobbying for tax or other regulatory concessions. As Hemphill and Kahan suggest, "A wholesale dilution of [executive] incentives makes sense, if at all, only for firms where the bulk of managerial effort otherwise would be devoted to competition at the expense of other [commonly owned] portfolio firms." 139

This is the key difference between WPS and RPE, and the key reason that WPS is a less plausible lever for managing executive incentives than RPE. Strong WPS incentives with low RPE would encourage a focus on overall profitability but not fierce competition with rival firms, whereas strong WPSand RPE-based incentives would encourage that competition. ${ }^{140}$ Common

\footnotetext{
135 See infra Section III.B.2.

136 See infra Section III.B.3.

137 See generally Azar, Schmalz \& Tecu, supra note 3; Azar, Raina \& Schmalz, supra note

3.

138 AEGS (2018), supra note 5, at 1-4.

139 Hemphill \& Kahan, supra note 28 (manuscript at 21).

140 This statement is true assuming that a competition-inducing RPE metric, such as total shareholder return, is utilized. See supra text accompanying notes 98-99. Of course, WPS and RPE are likely to be correlated to some extent, and WPS might be viewed as a proxy for RPE, but the point remains that RPE should be a more promising place to look for incentive management than WPS.
} 
owners should strongly prefer the former over the latter and the former over weak WPS incentives generally.

Moreover, the largest institutional investors - both the index fund families but also other large institutional investors - claim that they care about and work to achieve executive pay arrangements that encourage strong performance. The proxy-voting guidelines of these investors uniformly stress the importance of compensation programs that align the interests of executives with those of shareholders and create an effective link between executive pay and performance. ${ }^{141}$ Some investors state that they will not support pay arrangements that insufficiently link pay with performance. ${ }^{142}$

Of course, one might object that the stated preferences of institutional investors for strong incentives should be discounted as cheap talk. How likely is it that institutional investors would publicly announce that they do not care about executive pay or actually prefer weak incentives at commonly owned companies, even if it were true? Unfortunately, there is no direct evidence revealing how common owners vote on or otherwise influence executive pay, but we do know that institutional investors are not totally passive on the executive-pay front. Since 2011, U.S. public companies have been required to hold a nonbinding shareholder vote on the acceptability of senior executive pay at least once every three years. ${ }^{143}$ While a large majority of shareholders approve most of these "say on pay" proposals, ${ }^{144}$ institutional investors not infrequently

141 See BlackRock, supra note 76, at 11 ("BlackRock supports equity plans that align the economic interests of directors, managers, and other employees with those of shareholders."); CAPITAL GROUP, supra note 76 ("Compensation should create incentives for superior investment returns and align management's long-term interests with those of the shareholders."); FIDELITY, supra note 76, at 6 ("Fidelity generally will support proposals to ratify executive compensation unless the compensation appears misaligned with shareholder interests ...."); VANGUARD, Proxy Voting Guidelines For U.S. PORTFOLIO COMPANIES 12 (2019) (noting that "[a]lignment of pay and performance" is one category of considerations in executive compensation decisions and that "[i]n general, a fund ... will support [executive compensation proposals] that enhance long-term shareholder value"); 2019 Proxy Voting and Engagement Guidelines: North America (United States \& Canada), St. Street Global ADVISORS (Mar. 18, 2019), https://www.ssga.com/our-insights/viewpoints/2019-proxyvoting-and-engagement-guidelines-north-america.html ("[SSGA] believes executive compensation plays a critical role in aligning executives interest with shareholder's ... [and] support[s] management proposals on executive compensation where there is a strong relationship between executive pay and performance over a five-year period.").

142 See, e.g., BLACKRock, supra note 76, at 11 (stating intention to oppose executive pay plans that exhibit a "pay-for performance disconnect"); VANGUARD, supra note 141, at 12-13 (noting objectionable features of executive pay plans).

143 Dodd-Frank Wall Street Reform and Consumer Protection Act, Pub. L. No. 111-203, $\S 951,124$ Stat. 1376 (2010) (codified at 15 U.S.C. $§ 78 n-1$ ).

144 While between $1 \%$ and $3 \%$ of say-on-pay votes fail each year, that is, achieve less than $50 \%$ shareholder approval, in aggregate over $90 \%$ of individual say-on-pay votes have been "yes" votes. Semler Brossy, 2018 Say on PAy AND Proxy Results 6 (2018), 
vote "no." A recent study found that the median of the largest twenty-five institutional investors voted "no" on say-on-pay proposals $8.2 \%$ of the time in $2016 .{ }^{145}$ The study also found a close correlation between the votes of many of these investors and the recommendations of ISS and/or Glass Lewis, suggesting that the emphasis of the proxy advisory firms on pay for performance translates into say-on-pay voting by at least some large institutional investors that are likely to be common owners. ${ }^{146}$ In addition, Jill Fisch, Darius Palia, and Steven Solomon examined say-on-pay voting at S\&P 1500 companies between 2011 and 2016 and found some evidence that the sensitivity of pay to company performance has a statistically significant impact on voting outcomes. ${ }^{147}$ Of course, none of this evidence establishes that institutional investors impose discipline on pay practices with equal vigor at companies in industries with heavy common ownership. However, the point holds that the adoption of weak incentives generally would seem to run counter to interest, particularly as contrasted with the adoption of strong WPS incentives with little or no RPE.

2. Executive WPS Is Difficult to Adjust over the Short to Medium Term

Perhaps because it is difficult to envision common owners actively advocating for weak incentives, AEGS suggest that their results may be explained by common owners remaining passive while blockholders in industries that lack heavy common ownership aggressively pursue high-powered incentives. ${ }^{148}$ They do not directly test for the presence or absence of large, unconflicted blockholders, but this proposed mechanism is consistent with both their primary findings and the findings of an analysis of a natural experiment. ${ }^{149}$ In 2009 , BlackRock acquired BGI, combining the investment portfolios of the sixth largest (BlackRock) and the largest (BGI) asset managers at the time and increasing the amount of common ownership within a number of industries. ${ }^{150}$ AEGS's difference-in-differences analysis compares executive WPS in industries that experienced a large increase in common ownership as a result of

https:/www.semlerbrossy.com/wp-content/uploads/SBCG-2018-SOP-Report-06-06-

2018.pdf [https://perma.cc/P4VS-VK8E] (detailing say-on-pay voting results at Russell 3000 companies from 2011 through 2018).

145 Michael Keebaugh, Kelly Malafis \& Robert Martin, CAPFlash: Institutional Shareholder Voting Practices for SAY on PAY 1 (2016), https://www.capartners.com /wp-content/uploads/news/id317/capartners.com-capflash-issue92.pdf $\quad[$ https://perma.cc /QC2S-GEV3]. The institutional shareholder at the twenty-fifth percentile voted no $4.3 \%$ of the time and the shareholder at the seventy-fifth percentile voted no $11.7 \%$ of the time. $I d$.

$146 \mathrm{Id}$.

147 See Jill Fisch, Darius Palia \& Steven Davidoff Solomon, Is Say on Pay All About Pay? The Impact of Firm Performance, 8 HARV. Bus. L. Rev. 101, 103 (2018).

148 See AEGS (2018), supra note 5, at 4.

149 See id. at 27.

150 Table: The P\&I/Watson Wyatt World 500, supra note 128. 
the BlackRock/BGI merger with WPS in industries in which common ownership was less affected by the merger. They find that, in industries more greatly affected by the merger, WPS was relatively lower in the three years following the merger, suggesting that common ownership levels affect pay design. ${ }^{151}$

There are two possible, non-mutually exclusive explanations for the BlackRock/BGI results: First, companies in industries that experienced large increases in common ownership might have reduced executive WPS while WPS in other industries remained unchanged. Second, these companies might have maintained current levels of WPS while companies in other industries increased WPS. The latter explanation is consistent with AEGS's suggested mechanism, but neither explanation seems likely, particularly given the three-year period of analysis pre- and post-merger.

It will be helpful to consider how companies actually create and manage wealth-based executive incentives. It will be readily apparent that while companies undoubtedly manage these incentives over the long term, they make little effort and have little scope to do so over the short to medium term.

WPS is primarily a function of shares and options held by an executive, including equity held contingently upon satisfaction of vesting conditions and shares and options held outright. Thus, we can think of WPS arising from three sources - current year compensation, outstanding equity awards from previous years, and ownership of vested shares and options. The extent to which companies can and do adjust WPS differs among these sources.

\section{a. Adjusting WPS Through Current Compensation}

Companies could most readily adjust WPS by adjusting the terms of current compensation. They could do so without affecting total pay by shifting compensation between channels that are not sensitive to company performance (i.e., salary) and channels that are sensitive (i.e., annual bonuses and equitybased pay). However, companies traditionally have not varied salary significantly from year to year. We observe significant variation from year to year in the type and amount of equity-based pay issued to executives (and thus total pay), but we do not commonly observe tradeoffs between salary and equitybased pay. Companies could also adjust WPS by shortening or lengthening the vesting periods - essentially the holding periods - for various equity awards, but these vesting periods tend to be both uniform and sticky.

Let us begin by considering why companies do not tend to tweak the allocation of pay between salary and performance-sensitive pay channels. One reason is tax. In 1992, Congress limited the deduction for senior executive pay to $\$ 1$ million per executive per year, but created an exception for performancebased pay that was sufficiently broad so as to include properly designed annual

151 AEGS (2018), supra note 5, at 27. 
bonuses and certain equity-based pay. ${ }^{152}$ But salary in excess of $\$ 1$ million per year was clearly not deductible, and for years many companies limited salaries to $\$ 1$ million to avoid delivering nondeductible compensation dollars. ${ }^{153}$ On the other hand, companies that paid senior executives salaries less than $\$ 1$ million per year prior to 1993 tended to raise salaries to reflect the new "cap." 154 So the tax rule tended to create both a ceiling and a floor for senior executive salaries and to inhibit variability.

Another reason that we may not observe tradeoffs between salary and equitybased pay is that these channels of compensation are thought to serve very different purposes. Salary is generally viewed as providing basic financial security, while equity-based pay is intended to incentivize risk taking, reward success, and enhance retention. ${ }^{155}$ Whatever the reason, the empirical evidence suggests that equity compensation grants are not fully offset by reductions in base pay. ${ }^{156}$ So while companies could adjust the sensitivity of current compensation to company performance year by year by shifting compensation dollars between salary and equity-based pay, there is no evidence that they do so. Of course, companies can and do adjust WPS when they increase or decrease equity pay grants, but obviously this affects an executive's total compensation as well as WPS.

Companies also could adjust the WPS associated with current compensation by changing the terms - most directly the vesting terms — of equity-based pay.

152 See Omnibus Budget Reconciliation Act of 1993, Pub. L. No. 103-66, § 13211, 107 Stat. 312, 469-70 (codified as amended at I.R.C. $§ 162(\mathrm{~m})$ ). Section 162(m) was amended by the Tax Cuts and Jobs Act (TCJA) of 2017, Pub. L. No. 115-97, § 13211(a), 131 Stat. 2054, 2155-56 (codified at I.R.C. $\S 162(\mathrm{~m})$ ), to deny deductibility for all senior executive pay in excess of $\$ 1$ million per year, regardless of any performance linkage.

153 See, e.g., Tod Perry \& Marc Zenner, Pay for Performance? Government Regulation and the Structure of Compensation Contracts, 62 J. FIN. ECON. 453, 456 (2001) (finding reductions in salary and reduced salary growth at companies affected by $\S 162(\mathrm{~m})$ ).

154 See, e.g., David G. Harris \& Jane R. Livingstone, Federal Tax Legislation as an Implicit Contracting Cost Benchmark: The Definition of Excessive Executive Compensation, 77 ACCT. REV. 997, 1015 (2002) (finding that companies unaffected by $\S 162(\mathrm{~m})$ limited increases in CEO cash compensation in proportion to the extent that pay was expected to be below the $\$ 1$ million benchmark).

155 See, e.g., Yale D. Tauber, A Perspective on Executive Compensation, in EXECUTIVE Compensation 1, 4 tbl.1-1 (Yale D. Tauber \& Donald R. Levy eds., 2002).

${ }^{156}$ Matthias Benz, Marcel Kucher \& Alois Stutzer, Are Stock Options the Managers' Blessing? Stock Option Compensation and Institutional Controls 22 (Zurich Inst. for Empirical Research in Econ., Working Paper No. 61, 2001), https://papers.ssrn.com/sol3 /papers.cfm?abstract_id=251009 [https://perma.cc/3DNC-5Q3M]; Marianne Bertrand \& Sendhil Mullainathan, Do CEOs Set Their Own Pay? The Ones Without Principles Do 6 (Nat'1 Bureau of Econ. Research, Working Paper No. 7604, 2000), https://www.nber.org /papers/w7604.pdf [https://perma.cc/JRG7-Y6AZ]. 
Most public companies make equity grants to executives on an annual basis. ${ }^{157}$ Given that executives often dispose of equity-based pay upon vesting, ${ }^{158}$ equitybased pay that vests in five years creates greater WPS than equity-based pay that vests in three years. ${ }^{159}$ But again, we rarely observe year-to-year variation in the vesting terms attached to equity-based pay. When options reigned supreme, these instruments generally vested over a three- to five-year period and were generally exercisable at the recipient's discretion for up to a decade after issuance. ${ }^{160}$ Today, performance share schemes dominate, ${ }^{161}$ but again the vesting periods are relatively uniform and quite sticky. Most plans deliver shares or the cash-equivalent after a three-year performance period. ${ }^{162}$ And again, we rarely observe year-to-year variation in the length of the performance period. It does not appear that companies tweak the vesting terms of equity-based pay to adjust WPS.

Contrast the difficulty of adjusting WPS over the short term with the ease of adjusting RPE. Given the complexity and heterogeneity of RPE-based compensation, it would be unremarkable for a company to grant a performance award in one year that incorporates strong RPE-based metrics and benchmarks, and in a second year to select weaker RPE metrics and benchmarks or to replace RPE metrics with absolute, i.e., firm-specific, metrics. This can be done without making any tradeoff with salary or other pay that is not based on performance. To be sure, most performance awards measure results over a three-year period, but in the span of three years, a company could shift from strong RPE to no RPE or vice versa, changes that would have little or no impact on WPS. ${ }^{163}$

157 In 2016, for example, 86\% of the public-company senior executives whose compensation is reported in the Compustat ExecuComp database received some form of equity compensation grant (author's calculation).

158 See Alex Edmans, Vivian W. Fang \& Katharina A. Lewellen, Equity Vesting and Investment, 30 REV. FIN. STUD. 2229, 2230 (2017) (noting that executive equity sales are highly correlated with vesting).

159 Suppose, for example, that ACME issues its CEO 1000 shares of stock each year that vest in three years and that the CEO immediately sells the vested shares. In steady state, the CEO will hold 3000 unvested shares at any time. If the vesting period is increased to five years, she will hold 5000 unvested shares at any time.

160 See Kevin J. Murphy, Executive Compensation, in 3 HANDBOOK OF LABOR ECONOMICS 2485, 2507-10 (Orley Ashenfelter \& David Cards eds., 1999). These option-vesting practices remain prevalent today. See FW COOK, supra note 61 , at 13 (stating that $97 \%$ of 250 largest S\&P 500 companies surveyed in 2018 reported that their option grants vested in three to five years).

161 See supra Section II.B.

162 See FW CoOK, supra note 61, at 17 (noting that $91 \%$ of surveyed companies reported measurement period of three years).

163 Compare, for example, two performance awards that are each expected to result in a CEO receiving 10,000 shares of stock after three years. One is based exclusively on firmspecific performance - no RPE — while the other includes only a single strong RPE-based 


\section{b. Adjusting WPS Through Previously Issued Compensation}

Short of dismissing executives prior to vesting, companies have essentially no ability to adjust WPS associated with equity-based pay issued in prior years. Once equity-based pay is issued, the vesting or holding periods, which largely determine the WPS-based incentives, are either fixed (restricted stock and performance shares) or are actually under the control of the executives (options). ${ }^{164}$ Post-issuance, companies do not retain discretion over vesting or exercise that might allow them to tweak WPS after the fact. To be sure, the number of shares underlying performance share grants is generally variable, but the targets are set at issuance and are not within a company's control. ${ }^{165}$

\section{c. Adjusting WPS Associated with Vested Stock}

Moreover, companies do very little to control executive ownership of vested shares, and to my knowledge they never cap executive ownership. To be sure, many companies have share-ownership guidelines for senior executives, but conventional wisdom suggests that these guidelines are rarely binding, either because they are modest compared to executive compensation levels, are satisfied by unvested equity pay, or are simply viewed as guidelines and not enforced as strict requirements. ${ }^{166}$

\section{$* * * * *$}

In sum, companies could manage WPS associated with current compensation by making adjustments to compensation mix or the vesting terms of long-term instruments, but they do not appear to make frequent changes in either. Companies have little scope to manage WPS associated with issued and unvested or vested equity. This is not to suggest that companies do not manage executive WPS. Of course they do, but only in the way that one adjusts the course of an oil tanker-very slowly.

As a result, it is difficult to fathom the idea that companies in industries with large holdings by BlackRock and/or BGI either consciously reduced executive WPS within three years of the acquisition in light of greater post-acquisition

metric. Since the executive is expected to receive 10,000 shares with either award, the WPS created by the two awards is the same, while the RPE characteristics are obviously quite different.

164 See supra notes 49 and 51.

165 Performance share plans with variable payouts linked to multiple performance targets result in an economic relationship between share price and payout that is very similar to that of an option. See Walker, supra note 43, at 413. AEGS's description of their methods is not sufficient to allow me to determine whether they take this "optionality" into account in measuring WPS.

166 See Nitzan Shilon, CEO Stock Ownership Policies-Rhetoric and Reality, 90 IND. L.J. 353, 357 (2015) (discussing these limitations and finding that such policies are "extremely ineffectual"). 
common ownership or failed to respond as companies in other industries took steps to increase WPS. ${ }^{167}$ Setting aside the question of whether BlackRock, one of the largest index-focused investors, would have an incentive to manage WPS and interfirm competition, ${ }^{168}$ the companies in industries that became more commonly owned after the BlackRock/BGI merger would have had no levers with which to reduce WPS associated with outstanding equity awards and the only means of reducing WPS associated with vested share holdings would have been to soften shareholding guidelines allowing executives to sell more shares, which, given the optics, seems unlikely. ${ }^{169}$ As a result, any reduction in WPS would have to have been achieved through adjustments to current compensation grants and, given the relatively short period of study, through reducing the size of equity grants rather than through shortening vesting periods.

Alternatively, companies in industries that became more commonly owned might have maintained WPS while companies in other industries increased WPS. But why would the BlackRock/BGI merger prompt an increase in WPS in industries unaffected or less affected by the merger? Of course, the timing might have been coincidental, but again, even if the companies in these other industries purposefully set out to increase WPS, the tools with which they could do so in a three-year period would be quite limited.

AEGS suggest that the absence of a large active blockholder without an interest in competing companies is the simplest mechanism explaining their findings. ${ }^{170}$ But in order to explain the results of the BlackRock/BGI difference in differences analysis, one would have to assume either the entry of new unconflicted blockholders into the industries that were less affected by the merger, or that existing unconflicted blockholders in these industries for some reason became more aggressive in managing WPS after the BlackRock/BGI merger. Otherwise, one must assume that companies in industries that became more heavily commonly owned actually reduced WPS. Neither explanation seems likely.

167 Cf. AEGS (2018), supra note 5, at 25-28 (finding evidence consistent with either or both phenomena).

168 See Hemphill \& Kahan, supra note 28 (manuscript at 40); supra note 33 and accompanying text.

169 Such a move might also have been irrelevant as executive share ownership guidelines generally are not binding. See Shilon, supra note 166, at 357.

170 See AEGS (2018), supra note 5, at 4 ("The simplest mechanism is that the absence of a large active blockholder (with a strong interest in the target firm and without interests in competitors) is associated with reduced efforts to design high-powered managerial incentives. In other words, common owners need not actively design flat incentives; they may merely fail to design steep ones the way a non-common owner would.”). 
3. Methodological Concerns with a WPS-Based Assessment of Incentives

In their revised draft paper, AEGS rely upon the sensitivity of executive wealth to own-firm performance to determine the strength of incentives in both their panel regressions and their difference-in-differences analysis of BlackRock's acquisition of BGI. Doing so, of course, requires calculation of WPS associated with shares owned outright as well as outstanding equity pay grants. Calculating WPS for complex, performance-based equity pay awards is exceptionally challenging, however, and it is unclear how AEGS have dealt with this task. It is difficult to have confidence in their empirical results without having confidence in this fundamental element of the analysis. ${ }^{171}$

AEGS say very little in their paper with respect to calculation of WPS. They note that they follow the approach utilized by Alex Edmans, Xavier Gabaix, and Augustin Landier in a 2008 article. ${ }^{172}$ Edmans, Gabaix, and Landier provide a detailed description of how they determined WPS, which is based on earlier work by Core and Guay. ${ }^{173}$ The basic idea is this: wealth associated with a share of stock held outright or with time-vested restricted stock, assuming that the shares ultimately vest, increases or decreases dollar for dollar with the company's share price, but the value of an option and wealth associated with an

171 A second, perhaps less significant, concern with AEGS's revised WPS-based approach is limited to their difference-in-differences analysis. There appears to be an at least equally plausible explanation for AEGS's finding of a relative reduction in WPS in more heavily commonly owned industries following BlackRock's acquisition of BGI that does not necessarily support their hypothesis. Suppose that, relative to BGI, BlackRock more aggressively pursued reductions in or limitations on executive pay. In fact, the most plausible mechanism for a post-merger reduction in WPS would be reduction in current year equity pay. Given the stickiness of salary and annual bonuses, it is likely that reductions in equity pay would not have been made up elsewhere. If BlackRock pushed harder on equity pay at companies in which it had a larger ownership position post-merger, reductions in current equity pay would translate into reduced WPS in each of AEGS's three WPS specifications, assuming that other elements of pay were unaffected. To be sure, one might also be surprised to learn that BlackRock aggressively monitors executive pay, see, e.g., Bebchuk \& Hirst, supra note 14 (manuscript at 47-48) (providing evidence that index fund managers tend to be deferential to management), but this idea seems at least as plausible as the idea that they monitor WPS in order to discourage interfirm competition. And, of course, if the postBlackRock/BGI merger evidence is about pay levels and not incentives, this evidence would not necessarily support the thesis that executive incentives are a mechanism linking common ownership with reduced competition.

172 AEGS (2018), supra note 5, at 22 (citing Alex Edmans, Xavier Gabaix \& Augustin Landier, A Multiplicative Model of Optimal CEO Incentives in Market Equilibrium, 22 ReV. FIn. STUD. 4881, 4881-917 (1990)).

173 See Edmans, Gabaix \& Landier, supra note 172, at 4898 app. B (citing John Core \& Wayne Guay, Estimating the Value of Employee Stock Option Portfolios and Their Sensitivities to Price and Volatility, 40 J. ACCT. RES. 613, 613-630 (2002)). 
option is related to share price in a more complex, nonlinear fashion. ${ }^{174}$ Economists use the term "delta" to describe the change in the value of a compensation instrument arising from a small change in the underlying share price. Restricted stock and stock held outright have a delta of one; options have a delta of less than one that depends on the current market price and volatility of the shares, the option exercise price, remaining time to expiration, etc. Although complex, option delta - like option value - can be easily estimated using the BSM methodology. ${ }^{175}$ The sum of the delta-weighted shares and options held by an executive is the key input into determining WPS. ${ }^{176}$

But what about performance shares? Performance shares were rare when Core and Guay published their work in 2002 and had only recently become important at the end of the period studied by Edmans, Gabaix, and Landier. ${ }^{177}$ Neither of these articles discusses performance shares. Both articles focus exclusively on stock (deemed to be time-vested only by implication) and conventional compensatory options. ${ }^{178}$ But unlike time-vested restricted stock, performance shares do not have delta equal to one. ${ }^{179}$ And, of course, performance shares now dominate the equity pay landscape.

Like determining value, determining the incentive characteristics of performance share grants is exceptionally complex. The complexity arises from the variable award schedule that is a function of absolute or relative performance (or both) with respect to market, accounting, or other measures. ${ }^{180}$ Moreover, while companies are required to disclose an ex ante value for these awards, they are not required to disclose their incentive characteristics.

The difficulty of determining incentive characteristics is multiplied when awards are based on multiple metrics, which is increasingly the case. Recognizing these challenges, Bettis, Bizjak, Coles, and Kalpathy elect to analyze the value and incentive characteristics of a limited subset of performance awards that include only a single, absolute performance metric. ${ }^{181}$ Even for this restricted sample of grants, they find it necessary to develop new simulation methods to study these awards. Having done so, they find that the addition of performance-vesting conditions amplifies incentives to increase shareholder value (i.e., increases compensation delta) versus purely time-vested restricted stock. ${ }^{182}$ Although they limit their analysis to single, absolute metric

\footnotetext{
174 See Walker, supra note 48, at 237.

175 Id. at 237-38.

176 Edmans, Gabaix \& Landier, supra note 172, at 4898.

177 Edmans, Gabaix, and Landier analyzed data for the 1992-2006 period. Id. at 4899.

178 Core and Guay's 2002 article only addresses the determination of value and incentive properties of options. See Core \& Guay, supra note 173, at 613.

179 Bettis et al., supra note 60, at 197.

180 Id.

${ }^{181} I d$. at $200,211$.

182 Id. at 212.
} 
awards, there is no reason to think that the outcome would be directionally different for more complex award types.

The upshot is that the WPS associated with performance shares is likely to be significantly different, and likely greater, than that associated with time-vested restricted stock, but the impact is a function of the metrics and benchmarks employed. In cases in which companies employ a combination of absolute and relative performance metrics, it will be exceptionally challenging to determine the delta and WPS associated with these grants.

If AEGS apply delta of one to all stock grants, whether time-vested alone or performance-vested, it is likely that they will have misestimated WPS associated with performance shares. Such misestimation is likely to be particularly significant for recent periods, including the years surrounding the BlackRock/BGI merger, in which performance share awards have been prevalent.

\section{TOWARD AN IMPROVED EMPIRICAL STRATEGY}

For the reasons discussed above, it seems unlikely that a negative causal relationship exists between institutional investor common ownership within an industry and the strength of executive incentives. Unfortunately, the empirical strategies used to date have not been sufficient to establish the presence of such an association or the lack thereof. This is an important gap since executive incentives are generally viewed as one of the more plausible mechanisms underpinning the broader claim of a link between common ownership and reduced competition. In the spirit of advancing the empirical analyses and resolving this important question, this Part offers some suggestions with respect to the executive-incentive side of the equation.

First, tests for a link between common ownership and executive incentives based on RPE seem more promising than tests based on WPS from both a theoretical and an empirical perspective. From a theoretical perspective, it makes more sense that common owners would favor strong performance-based incentives that lack RPE than weak incentives generally. ${ }^{183}$ Generally, weak incentives are simply too blunt an instrument for deterring competition. Also, it is easier to adjust RPE than WPS over the short or medium term. Given all of this, one would think that an empirical strategy focusing on RPE would be more likely to produce an association between common ownership levels and executive incentives, if an association is to be found.

But both approaches present empirical challenges. For RPE-based approaches, there is the problem that RPE can be implicit, explicit, or both. An improved empirical methodology must account for both implicit and explicit RPE. As discussed above, determining the sensitivity of total compensation to own-firm and rival-firm performance is an appropriate means of gauging

183 See Hemphill \& Kahan, supra note 28 (manuscript at 21-22) (reaching same conclusion). 
implicit RPE, but explicit RPE likely dominates in recent years, and it is difficult to quantify the economic magnitude of explicit RPE features of equity awards. ${ }^{184}$ DeSimone tests for a relationship between common ownership and firm use of explicit RPE, defined as any RPE-based award granted in a firm-year, and the relative size of RPE grants, measured as the grant-date value of awards that include RPE metrics as a fraction of the grant-date value of all long-term incentive awards. ${ }^{185}$ This is a good start, but even the latter measure is only a rough proxy for the incentive effects of RPE awards (and, of course, only accounts for explicit RPE). The RPE feature or features of a particular award can be central or they can be trivial. In addition to the relative size of awards, an improved approach could take into account available data (from ISS Incentive $\mathrm{Lab}$ ) on the following features:

(1) the number of RPE and non-RPE metrics in a particular award. An award with RPE metrics exclusively is likely to provide stronger RPE than an award that includes one or more absolute (non-RPE) metrics.

(2) the nature of the RPE metric. As Schmalz notes, metrics based on company value, such as total shareholder return, create incentives to compete for market share, while metrics that are based on margins likely discourage such competition. ${ }^{186}$

(3) the benchmark. Benchmarking RPE against a select group of peer firms provides the strongest incentive to compete. The use of an industry index provides a weaker incentive to compete. The use of a broad market index likely produces no additional incentive to compete with peer firms (relative to an award lacking RPE).

While an RPE-based empirical strategy seems clearly preferable to a WPSbased strategy, researchers should not completely ignore WPS. Imagine two executives with similar RPE-based incentives, but one has much larger share and option holdings, leading to much larger WPS. All else equal, the executive with large WPS will have a greater incentive to compete with rival firms (or do other things to increase share value). As such, WPS should at least serve as a control variable in the analysis. As noted above, determining WPS for performance awards is not trivial. Some rule of thumb may have to be developed to estimate WPS for these awards. Hopefully, however, this problem will be less acute if WPS serves as a control rather than as the dependent variable.

\section{CONCLUSION}

Given the seemingly inexorable rise in institutional investor ownership of U.S. equity securities and common ownership, the influence of common owners on competition is quickly becoming one of the most important topics in

184 See supra Part II.

185 DeSimone, supra note 6, at 20-23.

186 See Schmalz, supra note 41, at slide 63. 
corporate governance and regulation. The seriousness of the problem and the advisability of intervention is a matter of heated debate. A key question in this debate involves the mechanism that could translate anticompetitive incentives of common owners into anticompetitive behavior by corporate managers. Without a plausible mechanism, the arguments of proponents of regulatory intervention lose much of their force.

Executive pay design has been a leading candidate for that mechanism. As this Article has detailed, however, the evidence linking executive incentives with common ownership is actually quite weak. The macro-level trends in the use of explicit RPE and common ownership and the most commonly employed RPE design features run exactly counter to the mechanism hypothesis. And now, particularly given that AEGS have moved away from an RPE-based approach, the weight of the remaining empirical evidence does not support the suggestion that avoidance of RPE is a mechanism linking common ownership with diminished interfirm competition.

The dramatic increase in the explicit use of RPE-based compensation metrics over the last twenty years undermines not only the compensation mechanism, but also the passive or "do nothing" mechanism proposed by Azar, Schmalz, and Tecu. ${ }^{187}$ The idea here is that, unlike sole owners, common owners might simply do nothing to promote competition and allow managers to live the quiet life. Adopting RPE-based compensation, however, is exactly the opposite of doing nothing.

The related but slightly different idea that greater common ownership leads to reduced sensitivity of executive wealth to own-firm performance - that is, to lower-powered incentives generally-and thus to dampening interfirm competition seems implausibly overbroad. Moreover, this Article has offered several conceptual and methodological reasons to question the evidence offered by the sole paper adopting this approach to date. ${ }^{188}$

In sum, this Article has provided numerous reasons to conclude that executive pay design is an implausible mechanism linking common ownership with dampened competition. If accepted, these arguments tend to undermine the more general claim and add further cautionary notes to the debate regarding regulatory intervention.

However, this Article certainly does not purport to disprove the compensation hypothesis; instead, it claims that the existing evidence is weaker than is generally understood. As such, and despite skepticism regarding the hypothesis, this Article has also offered several suggestions for improving the compensation side of empirical analyses investigating the potential link between common ownership and executive incentives. My hope is that these suggestions will help analysts advance our understanding of this important issue.

187 See supra text accompanying note 32.

188 See generally AEGS (2018), supra note 5. 